\title{
Evaluating leaf litter beetle data sampled by Winkler extraction from Atlantic forest sites in southern Brazil
}

\author{
Philipp Werner Hopp ${ }^{1}$, Edilson Caron ${ }^{2}$, Richard Ottermanns ${ }^{1} \&$ Martina Roß-Nickoll $^{1}$
}

${ }^{1}$ Institute for Environmental Research, University of Aachen, Worringerweg 1, 52064 Aachen, Germany. philipp.hopp@bio5.rwth-aachen.de; ottermanns@bio5.rwth-aachen.de; ross@bio5.rwth-aachen.de

${ }^{2}$ Campus Palotina, Universidade Federal do Paraná, Rua Pioneiro, 2153, Jardim Dallas, 85950-000 Palotina-PR, Brazil. caron@ufpr.br

\begin{abstract}
Evaluating leaf litter beetle data sampled by Winkler extraction from Atlantic forest sites in southern Brazil. To evaluate the reliability of data obtained by Winkler extraction in Atlantic forest sites in southern Brazil, we studied litter beetle assemblages in secondary forests ( 5 to 55 years after abandonment) and old-growth forests at two seasonally different points in time. For all regeneration stages, species density and abundance were lower in April compared to August; but, assemblage composition of the corresponding forest stages was similar in both months. We suggest that sampling of small litter inhabiting beetles at different points in time using the Winkler technique reveals identical ecological patterns, which are more likely to be influenced by sample incompleteness than by differences in their assemblage composition. A strong relationship between litter quantity and beetle occurrences indicates the importance of this variable for the temporal species density pattern. Additionally, the sampled beetle material was compared with beetle data obtained with pitfall traps in one old-growth forest. Over $60 \%$ of the focal species captured with pitfall traps were also sampled by Winkler extraction in different forest stages. Few beetles with a body size too large to be sampled by Winkler extraction were only sampled with pitfall traps. This indicates that the local litter beetle fauna is dominated by small species. Hence, being aware of the exclusion of large beetles and beetle species occurring during the wet season, the Winkler method reveals a reliable picture of the local leaf litter beetle community.
\end{abstract}

KEYWORDS. Coleoptera; comparison; pitfall traps; sampling method; seasonality.

RESUMO. Avaliação dos besouros da liteira amostrados por extração Winkler na Floresta Atlântica do Sul do Brasil. Para avaliar a confiabilidade dos dados obtidos pela extração Winkler em coletas na Floresta Atlântica do Sul do Brasil, nós estudamos as assembléias de besouros da liteira em florestas secundárias (5 a 55 anos após abandono) e no estágio avançado em dois pontos no tempo sazonalmente diferentes. Para todos os estágios de renegeração, a densidade e abundância das espécies foram menores em abril comparado a agosto; porém, a composição das assembléias dos estágios florestais correspondentes foi similar em ambos os meses. Nós sugerimos que amostragens de pequenos besouros habitantes de liteira em diferentes pontos no tempo usando o método Winkler revelam padrões ecológicos idênticos. Um forte relacionamento entre a quantidade da liteira e a ocorrência de besouros indica a importância dessa variável no padrão temporal de densidade das espécies. Adicionalmente, o material amostrado foi comparado com dados de besouros obtidos utilizando armadilhas do tipo pitfall em um estágio avançado de regeneração. Cerca de $60 \%$ das espécies de interesse capturadas em pitfall foram também amostradas pela extração Winkler. Poucos besouros com tamanho corporal grande para ser amostrado pela extração Winkler foram capturados com a armadilha pitfall. Isso indica que a fauna local de besouros da liteira é dominada por espécies pequenas. Portanto, sabendo da exclusão das espécies grandes e das espécies que ocorrem durante a estação chuvosa, o método Winkler revela um cenário confiável da comunidade local de besouros da literia.

PALAVRAS-CHAVE. Armadilha pitfall; Coleoptera; comparação; métodos de amostragem; sazonalidade.

Data obtained in ecological studies deeply depend on the used sampling design and methodology. Most uncertainties of analysis results accrue from sample sizes too small for adequate power in tests of significance, the usage of "pseudoreplicates" instead of true replication and the missing knowledge of how well the spot sample represents the "target" population (see Hurlbert 1984; Eberhardt \& Thomas 1991). This is especially true for studies focusing on insect assemblages in tropical forests, where inventories are poorly known (Kim 1993; Stork 1994) and the environment is very heterogeneous. As sample size and number of true replicates are often influenced by limitations in time, manpower and cost effectiveness, the usage of sampling methods which focus on snap-shots of the population in space and time are popular, in particular for sampling leaf litter invertebrates such as beetles. However, occurrence and abundance of epigeic beetle assemblages can vary throughout the year, mediated by changing environmental conditions (Wolda 1988). Therefore, the reliability of results obtained by snapshot methods has to be evaluated.

Many studies focusing on inventories and comparing beetle assemblages, cope with the problem of fluctuating beetle occurrences by expanding the sampling time. This extension could encompass a vegetation period or several years. A commonly used sampling method for this approach is pitfall trapping (e.g., Work et al. 2002). Many studies using pitfall traps showed that beetle species occurrences change throughout the year or at least show clear seasonal abundance patterns (e.g., French \& Elliott 1999; Finn et al. 2001; JayRobert et al. 2008). These results support the necessity of 
long-term sampling using pitfall traps for ecological beetle studies. However, despite the advantages of using pitfall traps, this method bears many sources of error (Adis 1979). Numerous studies showed that catches are dependent on temperature (Raworth \& Choi 2001), vegetation structure and density (Topping \& Sunderland 1992; Melbourne 1999; Bonte et al. 2002), season (Raworth \& Choi 2001; Topping \& Sunderland 1992) and the activity of ground dwelling species (Morrill et al. 1990). Furthermore, the catches are influenced by the duration of sampling (Riecken 1999), the killing agent used (Weeks \& McIntyre 1997) and by species-specific escape abilities (Halsall \& Wratten 1988). Lang (2000) concluded that the relationship between pitfall trap catches and actual population densities appeared to be either absent, weak or highly variable among taxa, habitat and time of the season.

Litter sifting with Winkler extraction (Besuchet et al. 1987), an alternative sampling method which provides an area related measure of faunal assemblages independent of species activity, was shown to more efficiently sample ant species (Olsen 1991; Fisher \& Robertson 2002; Martelli et al. 2004; but, see Parr \& Chown 2001) and more adequately pictured ant (Ivanov \& Keiper 2009) and harvestmen (Bancila $\&$ Plaia ${ }^{\circ} u$ 2009) assemblages than did pitfall traps. We are not aware of any comparable study for beetles; however, results will surely depend on the beetle family studied. However, the Winkler method is, due to its destructive manner and its sensitivity to the actual moisture content of the sampled material, not suitable to sample insect assemblages over a longer time span or during periods of high precipitation.

Recently we analyzed leaf litter beetle data obtained using litter sifting with Winkler extraction in a chronosequence approach to evaluate the ecological response of leaf litter beetles to forest regrowth in the submontane Atlantic forest of Southern brazil (Hopp et al. 2010). In order to evaluate the reliability and suitability of using this method to generate ecological data for litter inhabiting beetle assemblages, we aimed in the present study to estimate the quality of data received by litter sifting.

First, we estimated the variations of beetle occurrences at two different points in time using litter sifting and Winkler extraction. The aim was to evaluate the variation of beetle assemblages at different points in time and to test if sample sets collected in a different season result in a similar recovery pattern during forest regeneration recently postulated by the authors (Hopp et al. 2010). Second, we examined, if litter quantity (revealed as regionally important factor for the diversity and distribution of litter beetles) affects a temporal pattern. This was done to distinguish between seasonal differences and environmental factor mediated differences in species density and abundance. Third, we analyzed beetle data, which was sampled using pitfall traps in one old-growth forest stand. The aim was to estimate, to which extent the litter sifting data reflected the data obtained from the pitfall trap sampling.

To accomplish these aims we answered the following research questions: 1) Do species density, abundance and composition of beetle species sampled by litter sifting differ between two sampling dates, featuring different environmental conditions? 2) Do beetle assemblages sampled by litter sifting at these different sampling dates show the same patterns along successional stages? 3) Does litter volume affect temporal variations in the species density pattern? 4) Is the "pitfall trap fauna" observed different to the "Winkler fauna"?

\section{MATERIAL AND METHODS}

Study sites and design. The study was conducted in submontane Atlantic forests, which are situated in the municipalities of Antonina and Guaraqueçaba, Paraná, Brazil. We installed study sites in different aged secondary forests (Stage 1: 8 yrs after abandonment; Stage 2: 12-15 yrs, Stage $3: 35-50 \mathrm{yrs}$ ) and old-growth forest ( $>100 \mathrm{yrs}$ ), which were located in the reserve Serra do Itaqui (Itaqui, Fig.1), owned by the NGO Sociedade de Pesquisa em Vida Selvagem (SPVS), to investigate the temporal variations in beetle occurrences sampled using the Winkler technique. All study sites were installed on cambisol to avoid effects of soil type on beetle density and composition. The study sites were scattered over the reserve to avoid bias due to spatial distance among replicate sites. Beetles were sampled in each study site at two sampling dates: April 2007 and August 2007. These sampling dates were chosen, because of two important reasons: First, April, which marks the end of the hot wet season and the beginning of the cool dryer season and August, which represents the end of the cool dryer season, are two seasonally different points in time, varying strongly in their environmental conditions. Second, the lower precipitation in these months sets suitable conditions for extracting beetles using the Winkler technique.

The beetles were sifted from leaf litter of twenty $1-\mathrm{m}^{2}$ quadrates per study site. One square meter $\left(1-\mathrm{m}^{2}\right)$ leaf litter samples were taken every $5 \mathrm{~m}$ along two parallel $50 \mathrm{~m}$ transects (separated by $20 \mathrm{~m}$ ). These were installed at least $50 \mathrm{~m}$ from the forest edge to exclude edge effects. The entire leaf litter of $1-\mathrm{m}^{2}$ forest floor, including little twigs and partly decomposed organic material, was sifted in several portions through a ten mm mesh by intensively shaking a bag-sieve for approximately one minute for each portion. After sifting, samples were transferred into a bag for transportation. Samples were extracted using the Winkler technique (Besuchet et al. 1987). The Winkler bags were suspended for 3 days, which could be shown suitable for a comparative leaf litter beetle survey (Krell et al. 2005). No further hand sorting was performed. To avoid great differences in moisture content of the sampled leaf litter, I only collected on dry days when there had been no rain the previous day. Nine beetle families (Staphylinidae, Curculionidae, Carabidae, Tenebrionidae, Eucinetidae, Leiodidae, Endomychidae, Hydrophilidae and Cerylonidae; here denoted as "reduced family set") were studied to characterize species density, abundance and assemblage composition of each study site. Staphylinidae, Curculionidae and Carabidae were chosen because of their high number of individuals in the samples. The less abun- 


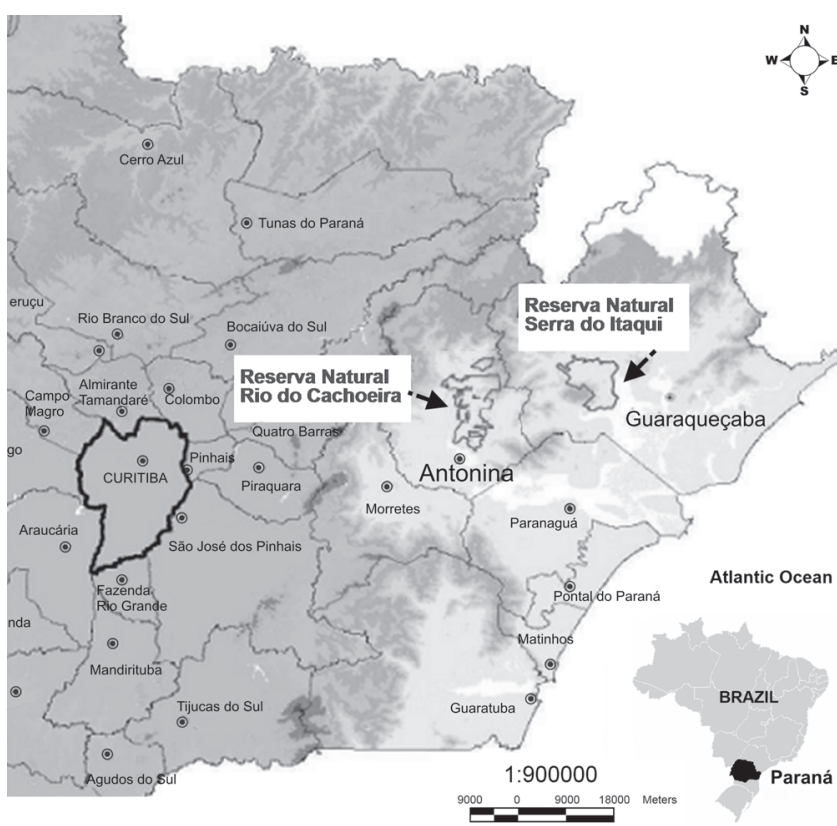

Fig. 1. Location of the two nature reserves Serra do Itaqui and Rio do Cachoeira owned by the NGO SPVS, in which the study sites were installed. The reserves are situated in the municipalities of Guaraqueçaba and Antonina, within the APA Guaraqueçaba, Paraná, Brazil.

dant families were chosen because of; (a) an adequate certainty of determination, due to large morphological variety (Tenebrionidae, Leiodidae) or moderate species numbers (Endomychidae, Eucinetidae, Cerylonidae), and (b) their presence in almost every investigated forest stage, which enabled a detection of species shift during secondary succession within beetle families (Hydrophilidae, Tenebrionidae). Additionally, the possibility to cooperate with specialists in some beetle families influenced the selection. The sampled individuals were sorted to morphospecies or, if possible, to species. Aleocharinae, Pselaphinae, Scydmaeninae (Staphylinidae), Scolytinae (Curculionidae) and the carabid genus Oxydrepanus were excluded due to uncertainties in the separation of morphospecies.

The pitfall trap sampling was conducted in one old-growth forest stand located in the reserve Rio do Cachoeira (Fig.1), owned by the NGO SPVS. The sampling was performed from March 2007 to July 2008. Ten traps were activated every month for one week making a total of 2856 trapping hours. Traps were filled with a $2-4 \%$ formaldehyde solution and were emptied after each sampling week to ensure a comparison of the monthly catches. Scydmaeninae (Staphylinidae) was excluded from further analysis due to very small catches and uncertainties in identification. Data from September and October 2007 had to be excluded from the analysis because several traps were destroyed by animals and flooded by rainfall.

Additionally, for the comparison of the beetle material gathered with the different sampling methods, we also used beetle data sampled by Winkler extraction in the same oldgrowth forest in the Rio do Cachoeira reserve. These data were collected between June-July 2003 using the same study design and sampling protocol explained for Itaqui (also see Hopp et al. 2010).

Data analysis. Temporal variations of the "Winkler fauna". To compare the species densities of the two sampling dates (Itaqui: April and August 2007) in each study site, we estimated the total number of beetle species per 20 $\mathrm{m}^{2}$ for each study site-sampling date combination using the Jackknife 1 richness estimator (PCOrd 5; McCune \& Mefford 1999). The cumulated number of individuals per study site was used to compare the abundances between the two sampling dates. A t-test or u-test (if data do not indicate normal distribution and equal variances) were conducted separately for every forest stage, to test for statistical difference between the sampling dates on a stage level. However, calculating the average species density or abundance of the different sampling dates on the basis of three replicates per stage could mask differences occurring on site level through high intra-site differences, which exceeds the site specific temporal differences. Therefore, a one-sided paired t-test was conducted among all sites to test for statistical difference between the sampling dates on site level (routine t.test in R, R Development Core Team 2009). Differences in assemblage composition among forest stages and sampling dates were analyzed using multi-response permutation procedure (MRPP; PCOrd 5). The pattern were visualized using nonmetric multidimensional scaling (NMDS, PCORD 5) ordination based on square root transformed data to down weight abundant species and Bray-Curtis distance measure.

Relationship of litter volume to species density. To test for differences in litter volume between the two sampling dates (Itaqui: April and August 2007), we compared the litter volumes of $20 \mathrm{~m}^{2}$ forest floor using a one-sided paired t-test (routine t.test in R). The according assumption of normal distribution was tested with the Lilliefors normality test (Dallal \& Wilkinson 1986; routine lillie from package nortest [Gross 2006] in R). Linear correlation analysis between beetle density and litter volume was performed using a linear model (routine $l m$ in R). Linear modeling was also used to calculate ANCOVA models, evaluating the differences in species density between the two sampling dates independently from litter volume.

"Pitfall trap fauna" vs. "Winkler fauna". Number of species and activity abundance of the pitfall trap catches were compared between the different sampling dates (= month) on the basis of; (1) all sampled beetle species (2) only the beetle species, which belong to the "reduced family set". For this, the catches of the ten pitfall traps were summed for each monthly sampling period. To evaluate the data quality and to verify if the monthly sampled numbers are biased by fluctuations in the completeness of the sampled data set, sample completeness was given for each month by dividing the number of species captured through the estimated total number of beetles calculated using the Jackknife 1 estimator (EstimateS, Colwell 2006). Additionally, captures per trap were given for single species, which showed high abundances and featured a 
noticeable abundance pattern. This was done to acquire an indication if differences in abundance are related to high numbers of catches in single traps and consequently could be coincidental rather than real abundance peaks.

To compare the beetle material gathered from the different methods, we explored which species caught with pitfall traps were also obtained by litter sifting, by comparing the set of species, belonging to the "reduced family set", sampled with pitfall traps in one old-growth forest with species data sampled by litter sifting; (i) at the same site in June-July 2003 (see Hopp et al. 2010), (ii) in old-growth forest sites of Itaqui sampled in August 2007, (iii) in old-growth forest sites of Itaqui sampled in April 2007 and (iv) in secondary forests (Stage 1-3) of Itaqui sampled in August/April 2007.

\section{RESULTS}

Beetle data. A total of 3210 beetles and 155 species were extracted from $440 \mathrm{~m}^{2}$ leaf litter in different forest stages of the Serra do Itaqui reserve using the Winkler technique (Appendix I).

In 2856 hours of pitfall trapping, using ten traps in one old-growth forest site, we sampled a total of 774 beetles representing 81 species. Most abundant families were Curculionidae (216 individuals), in particular Scolytinae (189), Staphylinidae (171), Hydrophilidae (96), Scarabaeidae (90) and Nitidulidae (85). Most abundant species were Scolytinae MS 4 (110 individuals), Hydrophilidae MS 3 (80) and Aleocharinae MS 55 (75). The proportion of singletons and doubletons using pitfall traps was comparably high (54\%) to that obtained by litter sifting (33-74\%).

Temporal variations of the "Winkler fauna". Species densities estimated (Jackknife 1) for $20 \mathrm{~m}^{2}$ forest floor were lower in April than in August (2007) in all sites, with the exception of one old-growth forest site (Fig. 2). Due to vast differences between the replicate sites of the different stages at both sampling dates, the differences in species density were not significant on stage level ( $\mathrm{t} / \mathrm{u}$-test, $\mathrm{n}=3$; Stage 1: $p=0.12$, Stage 2: $p=0.33$, Stage 3: $p=0.62$, Stage 4: $p=0.14$ ). However, a paired t-test among all sites showed that significantly more beetle species were sampled in August compared to April ( $\mathrm{n}=11, t=3.2611, d f=10, p=0.004$ ). Coinciding to the pattern of species density, we found significantly more beetle individuals in all study sites by sampling in August compared to April (Fig. 2). However, due to pronounced differences between the replicate sites, the abundances were not significantly different between the two sampling dates on stage level.

The beetle assemblage composition in sites of Stages 1 and 2 were very heterogeneous. They showed great differences between both the different sites and the sampling dates of the same site (Fig. 3). Accordingly, the assemblages of the study sites sampled in August and April (2007) were, due to the high inter-replicate differences, not significantly different for Stage 1 (MRPP, $\mathrm{n}=3, p=0.42$; significances for Stage 2 could not be calculated as only two replicate sites existed). The beetle assemblages of Stages 3 and 4 were much less
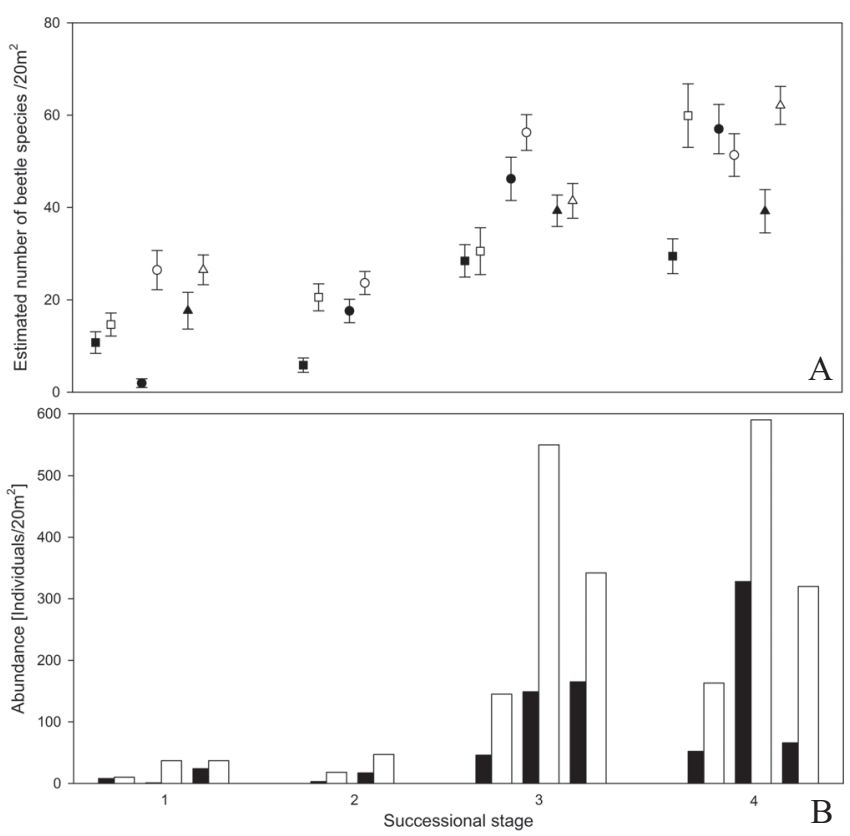

Fig. 2. Estimated total species density (A) and abundance (B) of $20 \mathrm{~m}^{2}$ forest floor at two different sampling dates in secondary forests and old-growth forests in submontane Atlantic forests of the Serra do Itaqui reserve, Brazil. Each study site (square: site 1, circle: site 2, triangle: site 3) of the different forest stages (1-4) was separately analyzed for sampling in April 2007 (full symbols/bars) and August 2007 (open symbols/bars). Species numbers are displayed as Jackknife 1 (Jack 1) estimation with standard deviation. Abundances are displayed as cumulative number of individuals for $201-\mathrm{m}^{2}$ samples.

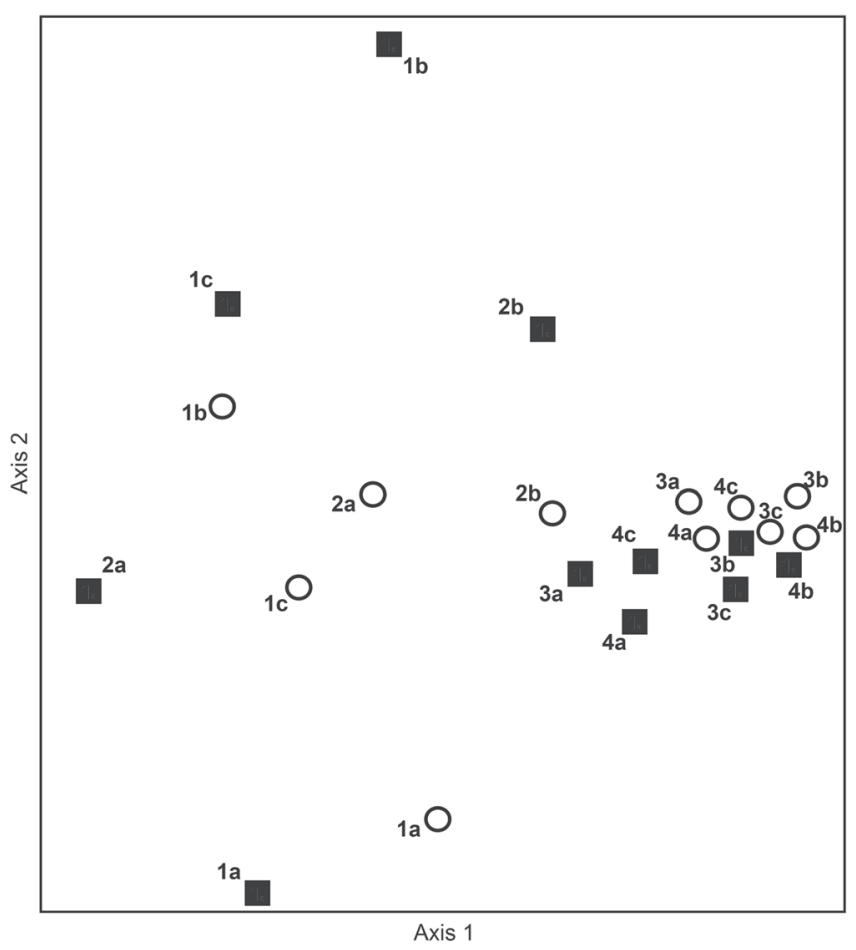

Fig. 3. Nonmetric multidimensional Scaling (NMDS) ordination of litter inhabiting beetle assemblages, according to successional stage (Stages 14, replicate sites a-c) and sampling date (full squares: April 2007, open circles: August 2007). Sites grouped closer together are more similar in species composition. 2D plot based on square root transformed abundance data and Bray-Curtis distance (final stress of solution: 0.17). 
variable (Fig. 3). Their assemblages were not notably different between the sampling dates (MrPP, $\mathrm{n}=3$, Stage 3: $p=0.20$; Stage 4: $p=0.34)$. Furthermore, Stages 3 and 4 showed no significant difference between each other independent of the sampling date. However, Stages 3 and 4 showed a significant different species composition compared to Stages 1 and 2.

Relationship of litter volume to species density. Litter volume were significantly higher in August 2007 compared to April 2007 (paired t-test: $t=7.9617, d f=10, p<0.001$ ). Linear correlation analysis, relating the estimated species density to the leaf litter volume of $20 \mathrm{~m}^{2}$ forest floor, revealed that the estimated number of species at all sites-sampling date combinations showed a strong linear relationship to litter volume for April as well as August (April: adjusted $\mathrm{R}^{2}=0.62$, $p=0.002$, August: 0.47 and 0.012 resp., Fig. 4). This correlation is so strong, that species density does not show a significant relation to sampling date anymore when partialling out the effect of litter volume first (see Table I).

"Pitfall trap fauna" vs. "Winkler fauna". Beetle catches with pitfall traps varied strongly among the monthly samplings; but showing no general difference between the wet season (December-March 2008) and the dryer season (June-
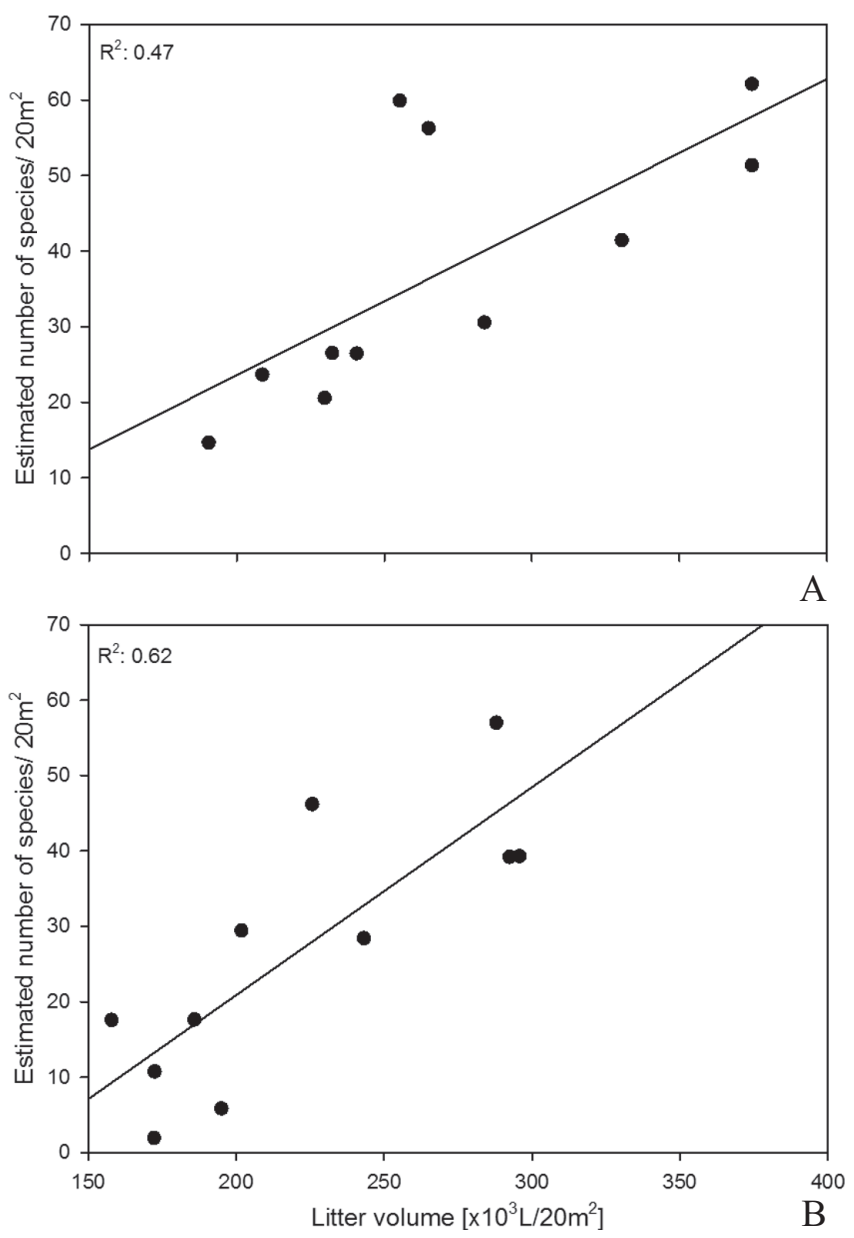

Fig. 4. Scatter plots of species density vs. litter volume per $20 \mathrm{~m}^{2}$ forest floor including linear correlation analysis for forests located in Itaqui reserve sampled in August (A) and April 2007 (B).
Table I. Results of ANCOVA on the effect of litter volume on beetle species density at two different sampling points. Litter volume was added as covariable and sampling date as fixed factor.

\begin{tabular}{lcc}
\hline & $\mathrm{t}$ value & $\mathrm{p}$ \\
\hline Intercept & -2.101 & 0.05001 \\
Litter & 3.829 & 0.00123 \\
Sampling date & 0.805 & 0.43123 \\
Sampling date x litter & -0.856 & 0.40334 \\
\hline
\end{tabular}

October 2007; Fig. 5). However, activity abundance curves for single species showed that a few abundant species (e.g. Deltochilum sp.1) occurred only in the rainy and the intermediate season, but, were absent in the dryer season (Fig. 6). Most species were caught in low abundances; some throughout the whole year showing no seasonal related occurrences or abundance peaks, others as singletons. Almost all species of the "reduced family set" belonged to this group.

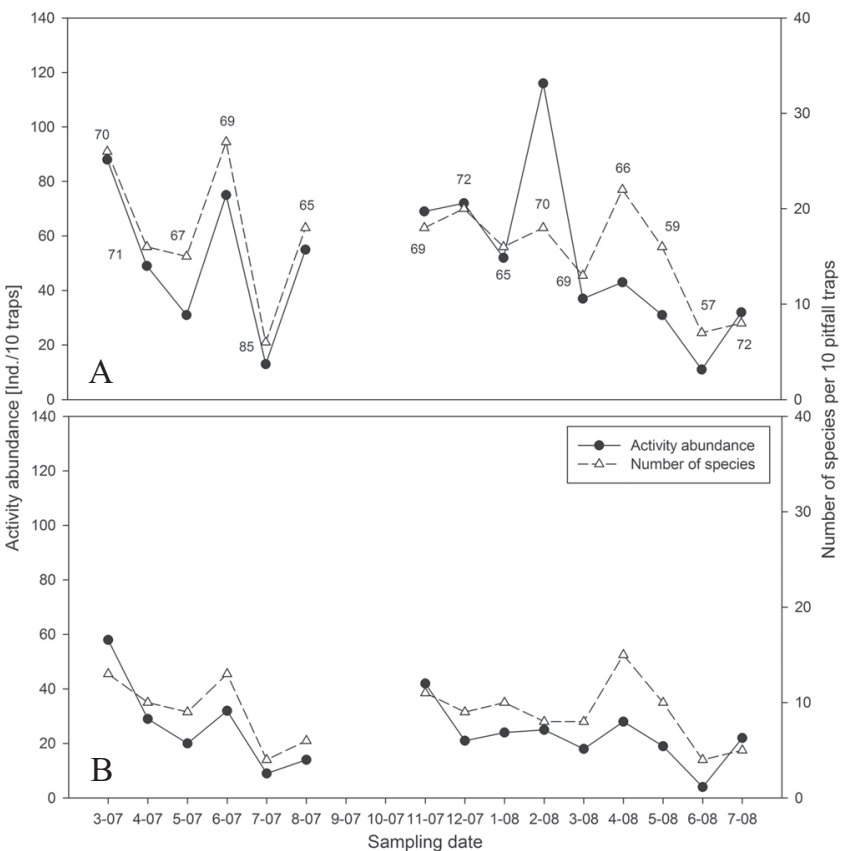

Fig. 5. Patterns for number of individuals (full circles, solid line) and species (open triangles, dashed line) captured with pitfall traps in an old-growth forest of Cachoeira reserve from March 2007 to July 2008. Curves were plotted for all species captured (A) and a reduced data set covering the species, which belonged to the beetle families also studied using litter sifting (B). September and October 2007 were excluded due to unreliable samples. Numbers in figure (A) indicate the percentage of sample completeness calculated by dividing the number of sampled species through the estimated total number of species using the Jackknife estimation.

From the total of 81 species captured with pitfall traps, 43 species $(53 \%)$ were members of the "reduced family set" (Table II). Sixty-two percent ( 27 species) of these 43 species were also found by litter sifting and Winkler extraction (Table II). We found 17 (40\%) of the 43 species by litter sifting in July 


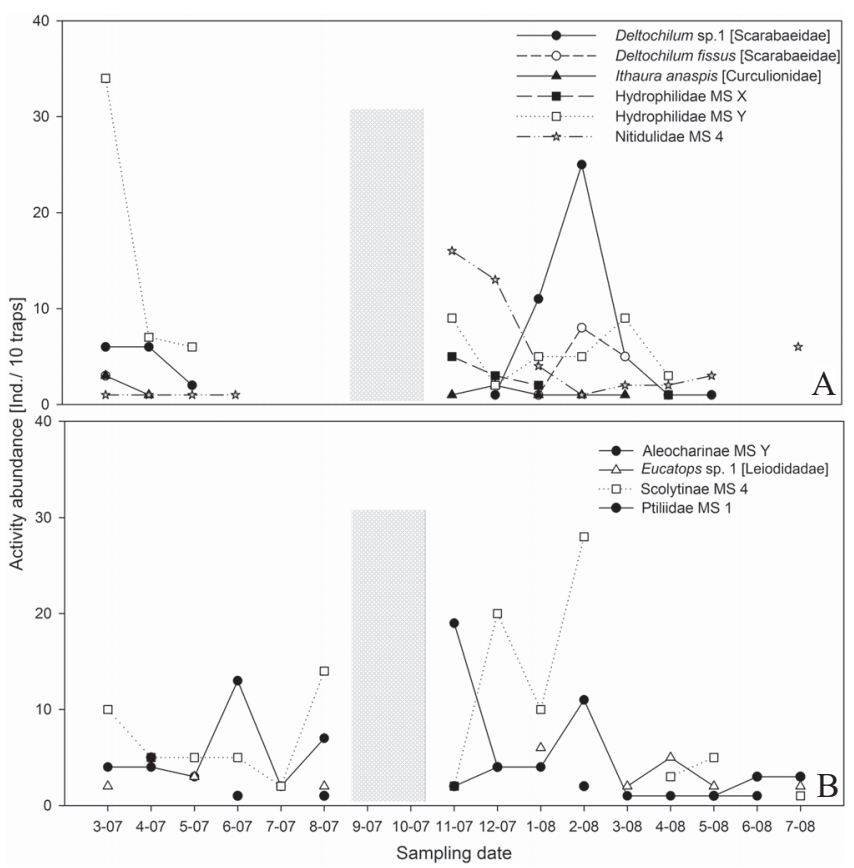

Fig. 6. Activity abundance curves for species sampled with pitfall traps in an old-growth forest from March 2007 to July 2008. Curves are presented for abundant species, which do not occur in the dryer season between June and October (A) and which occurred in all seasons (B). September and October 2007 were excluded due to unreliable samples.

2003 at the same study site (Table II, Stage 4 [C3F]). Eight of the 17 species were not captured during the dryer season using pitfall traps. Almost half (47\%) of the 43 species were found by litter sifting in the three old-growth forest sites of Itaqui reserve (April + August). However, none of these species were exclusively found by litter sifting in April 2007 (Table II). Many of the 43 species were also found in sites of other successional stages, mostly old secondary forests. The 16 species not found with litter sifting but captured with pitfall traps were mainly caught in low abundances. Except for the carabid species Pterostichini MS1, none of these species featured a notably larger body size than species of the "reduced family set". The species collected with pitfall traps which were not recognized by litter sifting belonged to the Scolytinae (Curculionidae), Histeridae, Nitidulidae, Cincindelidae and Aleocharinae (Staphylinidae). As Scolytinae (Curculionidae), Nitidulidae and Aleocharinae (Staphylinidae) were also frequently sampled by litter sifting but not further determined, these species cannot be compared between the two sampling methods. However, no histerid (2 species found with pitfall traps), cincindelid (1 species) nor scarabaeid (9 species) species were sampled by litter sifting at any sampling date, successional stage and location.

\section{DISCUSSION}

Temporal variations of the "Winkler fauna". Species density and abundance of litter beetles clearly differed between the two sampling dates: April and August 2007.
Surprisingly, more species with more individuals were sampled in August compared to April. This was quite unexpected, as April is temporally much closer to the wet season. This period has often shown to have higher species richness and abundance in tropical forests (at least at the beginning and the end of the wet season) compared to dryer phases throughout the year. Such increase of abundance and species richness near the wet season was shown for Chrysomelids in Araucaria forests (Linzmeier \& Ribeiro-Costa 2008), arboreal beetles of the tree Luehea seemannii in the canal zone of Panama (Erwin \& Scott 1980) or dung beetles in Costa Rican deciduous forests (Janzen 1983) and Mexican tropical dry forests (Andresen 2005). Reasons for the increase of abundance and species richness near the wet season were given as; (1) a higher availability of food resources, such as the flush of new leafs (Boinski \& Fowler 1989) or flowers (Kato et al. 2000), which often occurs at the beginning and the end of the wet season, (2) subsequent occurrences of predators through the increase of the abundance of its prey (Wolda 1978) or (3) rainfall adapted reproduction cycles (Hanski \& Cambeford 1991). In contrast to these results, Grimbacher \& Stork (2008), who studied the seasonality of beetles using Malaise and flight-interception traps in an Australian rainforest, found that although individual species were patchy in their temporal distribution, a wet season peak of insect activity could not be observed. They suggested that this could be due to a missing uniform pattern of insect seasonality for the humid tropics. Nevertheless, they showed that canopycaught and larger beetles $(>5 \mathrm{~mm})$ showed greater seasonality and peaked later in the year compared to smaller or groundcaught beetles. Boinski \& Fowler (1989), who investigated foliage phenology and arthropod abundance in a regenerating lowland rainforest of Costa Rica also found that in contrast to arboreal arthropods, the arthropod fauna of dead, suspended leafs showed little seasonality. Our results are in accordance with these findings as, in spite of differences in species density and abundance, the assemblage composition of mature forests was stunningly similar between the two sampling dates. Together, with results of the pitfall trap sampling one can surmise that the micro-beetle assemblages of Atlantic forest leaf litter vary to some degree throughout the year, otherwise show little seasonal trend (also see Smythe 1982). Clear differences between the two sampling dates of the young regeneration stages (Stages 1 and 2) reflect the differences between the replicate sites at the same sampling date and for that reason are most probably related to other causes than the temporal dynamics of their inhabiting species. Accordingly, the recovery pattern of species composition during forest regeneration was almost identical at the two sampling dates. Thus, we suggest that sampling at different points in time using the Winkler technique and focusing on small litter inhabiting beetles, reveals identical ecological patterns regarding forest regeneration. Furthermore, these patterns are identified by very similar data sets, whose deviations are more likely influenced by sample incompleteness than by strong differences in their assemblage composition. Similar beetle 
Table II. Comparison of the occurrence of beetle species (Curculionidae [excluding Scolytinae], Leiodidae, Carabidae [excluding Oxydrepanus], Staphylinidae [excluding Aleocharinae, Pselaphinae, Scydmaeninae], Tenebrionidae, Endomychidae, Eucinetidae and Hydrophilidae), sampled with pitfall traps in one old-growth forest site of Cachoeira reserve (C3F) from March 2007 to July 2008 with species data sampled by litter sifting; (i) at the same site (C3F) in June-July 2003, (ii) in old-growth forest sites of Itaqui reserve sampled in August 2007 (n = 3), (iii) in old-growth forest sites of Itaqui reserve sampled in April $2007(\mathrm{n}=3$ ) and (iv) in secondary forests (Stage 1-3) of Itaqui sampled in August/April 2007 (n=18). The pitfall trap catches were subdivided into four seasonal segments: wet season, intermediate months between wet season and dryer season, dryer season and intermediate months between dryer season and wet season. Catches in any month of a seasonal segment or by litter sifting at different sampling dates and successional stages are indicated by check marks, independent of the number of individuals found.

\begin{tabular}{|c|c|c|c|c|c|c|c|c|c|}
\hline \multirow{3}{*}{ Species } & \multirow{3}{*}{ Family } & \multicolumn{8}{|c|}{ Sampling method and sampling date } \\
\hline & & \multicolumn{4}{|c|}{ Pitfall trap (Stage 4, C3F, March 2007 - July 2008) } & \multicolumn{4}{|c|}{ Litter sifting } \\
\hline & & $\begin{array}{c}\text { Wet season } \\
\text { Dec-Mar }\end{array}$ & $\begin{array}{c}\text { Intermediate } \\
\text { Apr-May }\end{array}$ & $\begin{array}{l}\text { Dryer season } \\
\text { Jun-Sep }\end{array}$ & $\begin{array}{c}\text { Intermediate } \\
\text { Oct-Nov }\end{array}$ & $\begin{array}{c}\text { Stage } 4(\mathrm{C} 3 \mathrm{~F}) \\
\text { Cachoeira Jul-03 }\end{array}$ & $\begin{array}{c}\text { Stage } 4 \\
\text { Itaqui Aug-07 }\end{array}$ & $\begin{array}{c}\text { Stage } 4 \\
\text { Itaqui-Apr-07 }\end{array}$ & $\begin{array}{c}\text { Other } \\
\text { sites }\end{array}$ \\
\hline Ithaura anaspis & Curculionidae & $\checkmark$ & $\checkmark$ & $\otimes$ & $\checkmark$ & $\checkmark$ & $\checkmark$ & $\checkmark$ & $\otimes$ \\
\hline Tylodina MS 13 & Curculionidae & $\checkmark$ & $\checkmark$ & $\checkmark$ & $\otimes$ & $\checkmark$ & $\otimes$ & $\otimes$ & $\otimes$ \\
\hline Eucatops sp. 1 & Leiodidae & $\checkmark$ & $\checkmark$ & $\checkmark$ & $\checkmark$ & $\checkmark$ & $\checkmark$ & $\checkmark$ & $\checkmark$ \\
\hline Apenes sp. 1 & Carabidae & $\checkmark$ & $\checkmark$ & $\otimes$ & $\checkmark$ & $\checkmark$ & $\otimes$ & $\checkmark$ & $\checkmark$ \\
\hline Anotylus sp. 1 & Staphylinidae & $\checkmark$ & $\checkmark$ & $\checkmark$ & $\otimes$ & $\checkmark$ & $\checkmark$ & $\checkmark$ & $\checkmark$ \\
\hline Dibelonetes sp. 1 & Staphylinidae & $\checkmark$ & $\otimes$ & $\otimes$ & $\otimes$ & $\checkmark$ & $\checkmark$ & $\checkmark$ & $\checkmark$ \\
\hline Thinocharis sp. 1 & Staphylinidae & $\checkmark$ & $\otimes$ & $\checkmark$ & $\otimes$ & $\checkmark$ & $\checkmark$ & $\checkmark$ & $\checkmark$ \\
\hline Jentozkus sp. 1 & Eucinetidae & $\checkmark$ & $\checkmark$ & $\checkmark$ & $\otimes$ & $\checkmark$ & $\checkmark$ & $\otimes$ & $\checkmark$ \\
\hline Molytina MS 2 & Curculionidae & $\checkmark$ & $\otimes$ & $\otimes$ & $\otimes$ & $\checkmark$ & $\checkmark$ & $\checkmark$ & $\checkmark$ \\
\hline Tylodes sp. 1 & Curculionidae & $\otimes$ & $\checkmark$ & $\otimes$ & $\otimes$ & $\checkmark$ & $\otimes$ & $\otimes$ & $\checkmark$ \\
\hline Paulipalpina sp. 1 & Leiodidae & $\otimes$ & $\otimes$ & $\checkmark$ & $\otimes$ & $\checkmark$ & $\checkmark$ & $\checkmark$ & $\checkmark$ \\
\hline Anaedus sp. 3 & Tenebrionidae & $\otimes$ & $\checkmark$ & $\otimes$ & $\otimes$ & $\checkmark$ & $\checkmark$ & $\otimes$ & $\checkmark$ \\
\hline Anaedus sp. 4 & Tenebrionidae & $\otimes$ & $\checkmark$ & $\otimes$ & $\checkmark$ & $\checkmark$ & $\checkmark$ & $\checkmark$ & $\checkmark$ \\
\hline Echiaster sp. 1 & Staphylinidae & $\otimes$ & $\otimes$ & $\checkmark$ & $\otimes$ & $\checkmark$ & $\checkmark$ & $\checkmark$ & $\checkmark$ \\
\hline Platydema sp. 1 & Tenebrionidae & $\otimes$ & $\checkmark$ & $\checkmark$ & $\otimes$ & $\checkmark$ & $\checkmark$ & $\checkmark$ & $\checkmark$ \\
\hline Ibicarella sp. 1 & Endomychidae & $\otimes$ & $\checkmark$ & $\checkmark$ & $\otimes$ & $\checkmark$ & $\checkmark$ & $\checkmark$ & $\checkmark$ \\
\hline Xenaster sp. 1 & Staphylinidae & $\otimes$ & $\checkmark$ & $\otimes$ & $\otimes$ & $\checkmark$ & $\checkmark$ & $\checkmark$ & $\checkmark$ \\
\hline Conotrachelus sp. 1 & Curculionidae & $\checkmark$ & $\otimes$ & $\otimes$ & $\otimes$ & $\otimes$ & $\otimes$ & $\otimes$ & $\checkmark$ \\
\hline Dibelonetes sp. 4 & Staphylinidae & $\checkmark$ & $\otimes$ & $\otimes$ & $\otimes$ & $\otimes$ & $\otimes$ & $\otimes$ & $\checkmark$ \\
\hline Acarotopus sp. 1 & Staphylinidae & $\checkmark$ & $\checkmark$ & $\otimes$ & $\otimes$ & $\otimes$ & $\checkmark$ & $\checkmark$ & $\checkmark$ \\
\hline Loxandrus sp. 3 & Carabidae & $\checkmark$ & $\otimes$ & $\checkmark$ & $\otimes$ & $\otimes$ & $\checkmark$ & $\otimes$ & $\otimes$ \\
\hline Thinocharis sp. 2 & Staphylinidae & $\otimes$ & $\otimes$ & $\otimes$ & $\checkmark$ & $\otimes$ & $\checkmark$ & $\otimes$ & $\checkmark$ \\
\hline Paratachys sp. 2 & Carabidae & $\otimes$ & $\otimes$ & $\checkmark$ & $\checkmark$ & $\otimes$ & $\checkmark$ & $\checkmark$ & $\checkmark$ \\
\hline Pentagonica sp. 2 & Carabidae & $\otimes$ & $\otimes$ & $\checkmark$ & $\otimes$ & $\otimes$ & $\checkmark$ & $\otimes$ & $\otimes$ \\
\hline Leiodidae MS 2 & Leiodidae & $\otimes$ & $\checkmark$ & $\otimes$ & $\otimes$ & $\otimes$ & $\otimes$ & $\otimes$ & $\checkmark$ \\
\hline Cryptorhyn. MS 9 & Curculionidae & $\otimes$ & $\otimes$ & $\checkmark$ & $\otimes$ & $\otimes$ & $\otimes$ & $\otimes$ & $\checkmark$ \\
\hline Tylodina MS 12 & Curculionidae & $\otimes$ & $\checkmark$ & $\checkmark$ & $\checkmark$ & $\otimes$ & $\otimes$ & $\otimes$ & $\checkmark$ \\
\hline Anaedus sp.6 & Tenebrionidae & $\otimes$ & $\otimes$ & $\otimes$ & $\checkmark$ & $\otimes$ & $\otimes$ & $\otimes$ & $\otimes$ \\
\hline Anotylus sp.5 & Staphylinidae & $\checkmark$ & $\checkmark$ & $\checkmark$ & $\otimes$ & $\otimes$ & $\otimes$ & $\otimes$ & $\otimes$ \\
\hline Hydroph. MS 3 & Hydrophilidae & $\checkmark$ & $\checkmark$ & $\otimes$ & $\checkmark$ & $\otimes$ & $\otimes$ & $\otimes$ & $\otimes$ \\
\hline Hydroph. MS 4 & Hydrophilidae & $\checkmark$ & $\checkmark$ & $\otimes$ & $\checkmark$ & $\otimes$ & $\otimes$ & $\otimes$ & $\otimes$ \\
\hline Hydroph. MS 5 & Hydrophilidae & $\checkmark$ & $\checkmark$ & $\otimes$ & $\checkmark$ & $\otimes$ & $\otimes$ & $\otimes$ & $\otimes$ \\
\hline Hydroph. MS 6 & Hydrophilidae & $\checkmark$ & $\checkmark$ & $\otimes$ & $\otimes$ & $\otimes$ & $\otimes$ & $\otimes$ & $\otimes$ \\
\hline Thinocharis sp.4 & Staphylinidae & $\checkmark$ & $\otimes$ & $\otimes$ & $\otimes$ & $\otimes$ & $\otimes$ & $\otimes$ & $\otimes$ \\
\hline Tachyporinae MS 4 & Staphylinidae & $\checkmark$ & $\otimes$ & $\otimes$ & $\otimes$ & $\otimes$ & $\otimes$ & $\otimes$ & $\otimes$ \\
\hline Thoracophorus sp.4 & Staphylinidae & $\checkmark$ & $\otimes$ & $\otimes$ & $\otimes$ & $\otimes$ & $\otimes$ & $\otimes$ & $\otimes$ \\
\hline Euaestethinae MS 1 & Staphylinidae & $\checkmark$ & $\otimes$ & $\otimes$ & $\otimes$ & $\otimes$ & $\otimes$ & $\otimes$ & $\otimes$ \\
\hline Xantholini MS 2 & Staphylinidae & $\checkmark$ & $\checkmark$ & $\otimes$ & $\otimes$ & $\otimes$ & $\otimes$ & $\otimes$ & $\otimes$ \\
\hline Apenes sp.2 & Carabidae & $\checkmark$ & $\otimes$ & $\otimes$ & $\otimes$ & $\otimes$ & $\otimes$ & $\otimes$ & $\otimes$ \\
\hline Pterostichini MS 1 & Carabidae & $\checkmark$ & $\checkmark$ & $\otimes$ & $\otimes$ & $\otimes$ & $\otimes$ & $\otimes$ & $\otimes$ \\
\hline Anotylus sp.6 & Staphylinidae & $\otimes$ & $\checkmark$ & $\otimes$ & $\otimes$ & $\otimes$ & $\otimes$ & $\otimes$ & $\otimes$ \\
\hline Cryptorhyn. MS 10 & Curculionidae & $\otimes$ & $\otimes$ & $\checkmark$ & $\otimes$ & $\otimes$ & $\otimes$ & $\otimes$ & $\otimes$ \\
\hline Curculionidae MS 1 & Curculionidae & $\otimes$ & $\checkmark$ & $\otimes$ & $\otimes$ & $\otimes$ & $\otimes$ & $\otimes$ & $\otimes$ \\
\hline
\end{tabular}


recovery pattern found in Cachoeira reserve strongly support that assumption (Hopp et al. 2010).

But why did we find such great differences in species density and abundance between the sampling dates? We found an explanation for the difference in species density by measuring litter volume, which has already shown to substantially affect species density along the successional gradient (see Hopp et al. 2010). Regression analysis revealed that (1) species density was linearly correlated to the amount of leaf litter independent of the sampling date (see Fig. 4) and (2) that species density does not show a significant relation to sampling date anymore when partialling out the effect of litter volume first. Consequently, a strong interconnection between litter quantity and beetle occurrences seems to mediate abundance and species density, not only along a successional gradient, but also among seasonal variations of this physical parameter.

Nevertheless, a higher amount of leaf litter in August can be either a meaningful part of the temporal diversity patterns within tropical forests or be a sampling artifact. Both samplings were conducted by the same person using the same equipment and the same extraction protocol. As the seasonal differences in abundance are very high and are assumed to highly exceed the level of sampling inexactness, we rate operator related differences in the beetle data as negligible. Moreover, many studies showed that litter fall in tropical forests features a clear seasonal pattern, with generally higher litter fall in the dryer season compared to the wet season (Boinski \& Fowler 1989; Martínez-Yrízar \& Sarukhán 1990; Wieder \& Wright 1995). Therefore, higher litter fall in the months of the dryer season may provide more habitable substrate for litter inhabiting beetles and results in higher abundances and species densities without generally altering the beetle assemblage composition. This is indicated by low abundances of many additional species and by the presence of the most dominant species during both sampling dates. However, higher litter fall during and at the end of the wet season compared to the dryer season were recently measured in different stages of dune associated broad-leaf forests, which are situated close to the study area (personal communication K. Diekow [UFPR]). This indicates that further research has to be undertaken for a deeper understanding of the interaction between fluctuations in litter fall, litter volume and litter inhabiting beetle diversity in Brazilian Atlantic forest ecosystems.

Comparison of "Winkler fauna" and "pitfall trap fauna". Winkler extraction and pitfall traps are two commonly used sampling methods to explore epigeal beetle assemblages. In temperate regions pitfall traps were frequently used to study large ground related beetles, such as carabids (e.g., Niemelä et al. 1993; Heliölä et al. 2001). The Winkler technique was often used to sample less mobile, small bodied beetles, such as weevils (Besuchet et al. 1987). Thus, the Winkler extraction lacks a great portion of the beetle community, as the usage of a beetle sieve with a distinct mesh size of $\sim 1 \mathrm{~cm}$ excludes larger beetles per se.
Ten pitfall traps, which we installed in one Brazilian Atlantic old-growth forest, sampled with 365 individuals representing 21 species surprisingly few beetles. Over $60 \%$ of these species sampled with pitfall traps were also sampled by Winkler extraction. Although surely more large beetles would be found by expanding the sampling effort, it indicates that the local leaf litter beetle fauna is mainly constituted of small $(<3 \mathrm{~mm})$ to very small $(<1 \mathrm{~mm})$ beetles. This is congruent with findings of Hanagarth \& Brändle (2001) and Didham et al. (1998), who studied soil and litter inhabiting beetles in Amazonian forests.

Additionally, it shows that, whereas pitfall samples in the same area obviously add additional species by sampling throughout the year, most of these species would probably have already been obtained by the Winkler technique. This seems to be true for many beetle families in tropical forest litter, including the beetle families analyzed in this study; but, did not apply to some beetle families, which feature large species, such as Cincindelidae, Scarabaeidae or Nitidulidae as well as families which are known to strongly depend on high moisture levels, such as most Hydrophylidae. As a result, pitfall trapping seems to be essential if aiming to obtain a preferably complete species inventory of these families. However, the pitfall trap data failed to display a reliable picture of the beetle assemblages in leaf litter of the studied old-growth forest. Many very abundant beetle species were not sampled or only in very low abundances, suggesting enormous effort to get data sets, which are statistically analyzable. For this reason, being aware of the exclusion of large beetle species and those occurring in wet season, the Winkler method seems to reveal a much better picture of the litter inhabiting beetle community.

\section{CONCLUSIONS}

It is common knowledge that the choice of the sampling method strongly influences the resulting faunal assemblages (Kitching et al. 2001). Accordingly, the sampling method has to be chosen carefully when aiming to explore ecological patterns for distinct faunal assemblages, which should give basic data for conservation strategies. This is not only true for tropical forests and gains particular importance when examining ecological patterns for faunal groups seldom studied today, such as micro-beetle assemblages in Brazilian submontane Atlantic forest ecosystems.

This study provides the first results of comparing Winkler extraction and pitfall trap sampling for studying litter inhabiting beetle assemblages in Atlantic forests. The results revealed that Winkler extraction during the dryer season provides a suitable approach to study general ecological patterns of litter inhabiting beetle assemblages. By that means, similar results at two seasonally different points in time suggest that data obtained at one point in time are reliable and not strongly biased by seasonal dynamics of species presence and abundance. The strong relationship of the beetle data to litter volume confirms the important modulating character 
of this variable for species density and abundance, which seems to be stronger than species related seasonal dynamics, such as reproduction cycles.

However, pitfall traps provide important additional information about the beetle assemblages, which includes seasonal activity patterns of single species and temporal fluctuations in the assemblage composition, which are particular important for studying large beetles, such as tiger beetles or dung beetles. Thus, a combination of both methods is strongly recommended when time and manpower allow a comprehensive beetle survey. Additionally, the inclusion of long-term data makes a survey less prone to temporary phenomena which could influence the sampling output.

Nevertheless, our results indicate that the assumption, that if the aim of the study is to analyze the community pattern of litter inhabiting arthropods Winkler extraction could be more efficient than pitfall traps (e.g. stated from Bancila \& Plaia_u 2009 for harvestmen), is also true for litter beetles in Atlantic forests of Southern Brazil.

\section{ACKNOWLEDGEMENTS}

We thank the SPVS for access to the study sites and the SPVS and several colleagues of the Solobioma project for field work assistance. The study was embedded in the Project Solobioma, funded by the German Ministry of Education and Research (01LB0201) and the Brazilian Conselho Nacional de Desenvolvimento Científico e Tecnológico (160611).

\section{REFERENCES}

Adis, J. 1979. Problems of interpreting arthropod samplings with pitfall traps. Zoologischer Anzeiger 202: 177-184.

Andresen, E. 2005. Effects of season and vegetation type on community organization of dung beetles in a tropical dry forest. Biotropica 37 : 291-300.

Bancila, R. I. \& R. Plaia ${ }^{\circ}$ u. 2009. Sampling efficiency of pitfall traps and Winkler extractor for inventory of the harvestmen (Arachnida: Opilionidae). Travaux de L'Institut de Speologie Emile Racovitza 48: 5967.

Besuchet, C.; D. H. Burckhardt \& I. Löbl. 1987. The „Winkler/Moczarski” eclector as an efficient extractor for fungus and litter coleoptera. The Coleopterists Bulletin 41: 392-394.

Boinski, S. \& N. L. Fowler. 1989. Seasonal pattern in a tropical lowland forest. Biotropica 21: 223-233.

Bonte, D.; L. Baert \& J. P. Maelfait. 2002. Spider assemblage structure and stability in a heterogeneous coastal dune system (Belgium). Journal of Arachnology 30: 331-343.

Colwell R. K. 2006. EstimateS: statistical estimation of species richness and shared species from samples. version 8 . persistent available from URL: http://purl.oclc.org/estimates (accessed 23 September 2010).

Dallal, G. E. \& L. Wilkinson. 1986. An analytic approximation to the distribution of Lilliefors' test for normality. The American Statistician 40: 294-296.

Didham, R. K.; P. M. Hammond,; J. H. Lawton,; P. Eggleton \& N. E. Stork. 1998. Beetle species responses to tropical forest fragmentation. Ecological Monographs 68: 295-323.

Eberhardt, L. L. \& J. M. Thomas. 1991. Designing environ-mental field studies. Ecological Monographs 61: 53-73.

Erwin, T. \& J. C. Scott. 1980. Seasonal and size patterns, trophic structure and richness of Coleoptera in the arboreal tropical ecosystem: The fauna of the tree Luehea semannii Triana and Planch in the canal zone of Panama. The Coleopterists Bulletin 34: 305-322.

Finn, J. N. A.; T. Gittings \& P. S. Giller. 2001. Spatial and temporal variation in species composition of dung beetle assemblages in Southern Ireland. Ecological Entomology 24: 24-36.

Fisher, B. L. \& H. G. Robertson. 2002. Comparison and origin of forest and grassland ant assemblages in the High Plateau of Madagascar (Hymenoptera: Formicidae). Biotropica 34: 155-167.

French, B. W. \& N. C. Elliott. 1999. Spatial and temporal distribution of ground beetle (Coleoptera: Carabidae) assemblages in riparian strips and adjacent wheat fields. Environmental Entomology 28: 597-601.

Grimbacher, P. S. \& N. E. Stork. 2008. Seasonality of a diverse beetle assemblage inhabiting lowland tropical rain forest in Australia. Biotropica 41: 323-337.

Gross, J. 2006. Database: The Comprehensive R Archive Network (CRAN). Available from: http://cran.r-project.org/web/packages/nortest/. htm (accessed 10 February 2010).

Hanagarth, W. \& M. Brändle. 2001. Soil beetles (Coleoptera) of a primary forest, secondary forest and two mixed polyculture systems in central Amazonia. Andrias 15: 155-162.

Hanski, I. \& Y. Cambeford. 1991. Dung beetle ecology. Princeton, Princeton University Press, 520 p.

Halsall, N. B. \& S. D. Wratten. 1988. The efficiency of pitfall trapping for polyphagous predatory Carabidae. Ecological Entomology 13: 293-299.

Heliölä, J.; M. Koivula \& J. Niemelä. 2001. Distribution of carabid beetles (Coleoptera, Carabidae) across a boreal forest clearcut ecotone. Conservation Biology 15: 370-377.

Hopp, P. W.; Ottermanns, R.; Caron E.; S. Meyer \& M. Roß-Nickoll. 2010. Recovery of litter inhabiting beetle assemblages during forest regeneration in the Atlantic forest of Southern Brazil. Insect Conservation and Diversity 3: 103-113.

Hurlbert, S. H. 1984. Pseudoreplication and the design of ecological field experiments. Ecological Monographs 54: 187-211.

Ivanov, K. \&. J. Keiper. 2009. Effectiveness and biases of Winkler litter extraction and pitfall trapping for collecting ground dwelling ants in northern temperate forests. Environmental Entomology 38: 1724-1736.

Janzen, D. H. 1983. Seasonal change in abundance of large nocturnal dung beetles (Scarabaeidae) in a Costa Rican decidious forest and adjacent horse pasture. Oikos 41: 274-283.

Jay-Robert, P.; J. P. Lumaret \& J. D. Lebreton. 2008. Dung beetle assemblages and their relationships with environmental factors (Aphodiinae: Geotropinae: Scarabaeinae). Annals of the Entomological Society of America 101: 58-69.

Kato, M.; T. Itioka; S. Sakai; K. Momose; S. Yamane; A. A. Hamid \& T. Inoue. 2000. Various population fluctuation patterns of light-attracted beetles in a tropical lowland dipterocarp forest in Sarawak. Population Ecology 42: 97-104.

Kim, K. C. 1993. Biodiversity, conservation and inventory: why insects matter. Biodiversity and Conservation 2: 191-214.

Kitching, R. L.; D. Li \& N. E. Stork. 2001. Assessing biodiversity “sampling packages": How similar are arthropod assemblages in different tropical rainforests? Biodiversity and Conservation 10: 793-813.

Krell, F.T.; A. Chung; E. deBoise; P. Eggleton; A. Giusti; K. Inward \& S. Krell-Westerwalbesloh. 2005. Quantitative extraction of macroinvertebrates from temperate and tropical leaf-litter and soil: efficiency and time-dependent taxonomic biases of the Winkler extraction. Pedobiologia 49: 175-186.

Lang, A. 2000. The pitfalls of pit falls. A comparison of pitfall trap catches and absolute density estimates of epigeal invertebrate predators in arable land. Anzeiger für Schädlingskunde 73: 99-106.

Linzmeier, A. M. \& C. S. Ribeiro-Costa. 2008. Seasonality and temporal structuration of Alticini community (Coleoptera, Chrysomelidae, Galerucinae) in the Araucaria forest of Parana, Brazil. Revista Brasileira de Entomologia 52: 289-295.

Martelli, M. G.; M. M. Ward \& M. A. Fraser. 2004. Ant diversity sampling on the Southern Cumberland Plateau: A comparison of litter sifting and pitfall trapping. Southeastern Naturalist 3: 113-126. 
Martínez-Yrízar, A. \& J. Sarukhán. 1990. Litterfall patterns in tropical decidious in Mexico over a five year period. Journal of Tropical Ecology 6: 438-444.

McCune, B. \& M. J. Mefford. 1999. PC-ORD. Multivariate Analysis of Ecological Data. Version 5.0, Gleneden Beach, MjM Software Design, $237 \mathrm{p}$.

Melbourne, B. A. 1999. Bias in the effect of habitat structure on pitfall traps: an experimental evaluation. Australian Journal of Ecology 24: 228-239.

Morrill, W. L.; D. G. Lester \& A. E. Wrona. 1990. Factors affecting efficiency of pitfall traps for beetles (Coleoptera: Carabidae and Tenebrionidae). Journal of Entomological Science 25: 284-293.

Niemelä, J.; D. Langor \& J. R. Spence. 1993. Effects of clearcut harvesting on boreal ground beetle assemblages (Coleoptera, Carabidae) in Western Canada. Conservation Biology 7: 551-561.

Olsen, D. M. 1991. A comparison of the efficacy of litter sifting and pitfall traps for sampling leaf litter ants (Hymenoptera, Formicidae) in a tropical wet forest, Costa Rica. Biotropica 23: 166-172.

Parr, C. \& S. L. Chown. 2001. Inventory and bioindicator sampling: testing pitfalls and Winkler methods with ants in a South African Savanna. Journal of Insect Conservation 5: 27-36.

Raworth, D. A. \& M. Y. Choi. 2001. Determining numbers of active carabid beetles per unit area from pitfall trap data. Entomologia Experimentalis et Applicata 98: 95-108.

R Development Core Team. 2009. R: A language and environment for statistical computing. Vienna, Austria. R Foundation for Statistical Computing. Available from http://www.r-project.org. htm (accessed 10 February 2010).
Riecken, U. 1999. Effects of short-term sampling on ecological characterization and evaluation of epigeic spider communities and their habitats for site assessment studies. Journal of Arachnology 27: 189_ 195

Smythe, N. 1982. The seasonal abundance of night-flying insects in a neotropical forest, p. 309-318. In: Leigh, E. G. Jr.; A. S. Rand \& D. M. Windsor (eds). The ecology of a tropical forest. Washington, DC, Smithsonian Institution Press, 503 p.

Stork, N. E. 1994. Inventories of biodiversity: more than a question of numbers, p. 81-100. In: Forey, P. I.; C. J. Humphries \& R. I. VaneWright (eds). Systematics and conservation evaluation. Oxford, Clarendon Press, $438 \mathrm{p}$

Topping, C. J. \& K. D. Sunderland. 1992. Limitations to the use of pitfall traps in ecological studies exemplified by a study of spiders in a field of winter wheat. Journal of Applied Ecology 29: 485-491.

Weeks, R. D. \& N. E. McIntyre. 1997. A comparison of live versus kill pitfall trapping techniques using various killing agents. Entomologia Experimentalis et Applicata 82: 267-273.

Wieder, R. K. \& S. J. Wright. 1995. Tropical forest litter dynamics and dry season irrigation on Barro Colorado Island, Panama. Ecology 76: 19711979.

Wolda H. 1978. Seasonal fluctuations in rainfall, food and abundance of tropical insects. Journal of Animal Ecology 47: 369-381.

Wolda H. 1988. Insect seasonality: Why? Annual Review of Ecology and Systematics 19: 1-18

Work, T. T.; C. M. Buddle; L. M. Korinus \& J. R. Spence. 2002. Pitfall trap size and capture of three taxa of litter dwelling arthropods: Implications for biodiversity studies. Environmental Entomology 31: 438-448.

Received 23/9/2010; accepted 3/5/2011

Editor: Rodrigo Krüger 
Appendix I. Beetles (Staphylinidae [excluding Aleocharinae, Pselaphinae and Scydmaeninae], Curculionidae [excluding Scolytinae], Carabidae [excluding Oxydrepanus], Endomychidae, Hydrophilidae, Tenebrionidae, Leiodidae, Cerylonidae, Eucinetidae) sampled by litter sifting and Winkler extraction in submontane secondary (Stage 1: 8 yrs, Stage 2: 12-15 yrs, Stage 3: 35-50 yrs) and old-growth forests ( $>100$ yrs) of the Serra do Itaqui reserve, Paraná, Brazil. Beetles were sampled at two different sampling dates: April and August 2007. a-c indicates the replicates of each forest stage.

\begin{tabular}{|c|c|c|c|c|c|c|c|c|c|c|c|c|c|c|c|c|c|c|c|c|c|c|c|c|c|}
\hline \multirow{3}{*}{ No. } & \multirow{3}{*}{ Species } & \multicolumn{24}{|c|}{ Sampling date and successional stage } \\
\hline & & \multicolumn{12}{|c|}{ July-August 2007} & \multicolumn{12}{|c|}{ April-May 2007} \\
\hline & & $1^{\mathrm{a}}$ & $1^{\mathrm{b}}$ & $1^{\mathrm{c}}$ & $2^{\mathrm{a}}$ & $2^{\mathrm{b}}$ & $2^{\mathrm{c}}$ & $3^{\mathrm{a}}$ & $3^{\mathrm{b}}$ & $3^{\mathrm{c}}$ & $4^{\mathrm{a}}$ & $4^{\mathrm{b}}$ & $4^{\mathrm{c}}$ & $1^{\mathrm{a}}$ & $1^{\mathrm{b}}$ & $1^{\mathrm{c}}$ & $2^{\mathrm{a}}$ & $2^{\mathrm{b}}$ & $2^{\mathrm{c}}$ & $3^{\mathrm{a}}$ & $3^{\mathrm{b}}$ & $3^{\mathrm{c}}$ & $4^{\mathrm{a}}$ & $4^{\mathrm{b}}$ & $4^{c}$ \\
\hline \multicolumn{26}{|c|}{ Staphylinidae } \\
\hline \multicolumn{26}{|c|}{ Paedarinae } \\
\hline 1 & Acarotopus sp. 1 & - & - & - & 1 & - & 4 & 5 & 10 & 6 & 8 & 5 & 5 & - & - & - & - & - & - & 2 & 1 & 3 & 1 & 1 & - \\
\hline 2 & Astenus sp. 1 & - & 3 & - & - & - & - & - & - & - & - & - & - & - & - & - & - & - & - & - & - & - & - & - & - \\
\hline 3 & Biocrypta sp. 2 & - & 1 & 2 & - & - & - & - & - & - & - & - & - & - & - & 8 & - & - & - & - & - & - & - & - & - \\
\hline 4 & Biocrypta sp. 5 & - & - & - & 1 & - & - & - & - & 2 & - & - & - & - & - & - & - & - & - & - & - & - & - & - & - \\
\hline 5 & Dibelonetes sp. 1 & - & - & - & - & - & - & 2 & 30 & 9 & 2 & 10 & 6 & - & - & - & - & - & - & 2 & 7 & 9 & - & 4 & - \\
\hline 6 & Dibelonetes sp. 2 & - & - & - & - & - & - & - & - & - & - & - & - & - & - & - & - & - & - & - & - & - & - & - & 1 \\
\hline 7 & Dibelonetes sp. 3 & - & - & - & - & - & 2 & - & - & - & 3 & 1 & 1 & - & - & - & 1 & - & - & - & - & 2 & 4 & 4 & 1 \\
\hline 8 & Dibelonetes sp. 4 & - & - & - & - & - & - & 1 & - & - & - & - & - & - & - & - & - & - & - & - & - & - & - & - & - \\
\hline 9 & Echiaster sp. 1 & - & - & - & 4 & - & 6 & 35 & 131 & 37 & 13 & 36 & 26 & - & - & - & - & - & 3 & 7 & 21 & 7 & 2 & 18 & 9 \\
\hline 10 & Homaeotarsus sp. 1 & - & 1 & 4 & - & 1 & 5 & - & - & - & - & - & - & - & - & 2 & - & - & 1 & - & - & - & - & - & - \\
\hline 11 & Homaeotarsus sp. 2 & - & - & 2 & - & - & - & - & - & - & - & - & - & - & - & - & - & - & - & - & - & - & - & - & - \\
\hline 12 & Homaeotarsus sp. 4 & - & - & 1 & - & - & - & - & - & - & - & - & - & - & - & - & - & - & - & - & - & - & - & - & - \\
\hline 13 & Ronetus sp. 1 & - & - & 1 & - & - & - & - & - & - & - & - & - & - & - & - & - & - & - & - & - & - & - & - & - \\
\hline 14 & Ronetus sp. 3 & - & - & 2 & - & - & 1 & - & 9 & - & - & 1 & 4 & - & - & 1 & 1 & 1 & - & - & - & - & - & - & - \\
\hline 15 & Scopaeus sp. 2 & - & - & - & - & - & - & - & - & - & - & - & - & 1 & - & - & - & - & - & - & - & - & - & - & - \\
\hline 16 & Stenopholea sp. 1 & - & - & - & - & - & - & - & 1 & - & - & 1 & - & - & - & - & 1 & - & - & - & - & - & - & 1 & - \\
\hline 17 & Suniotrichus sp. 1 & - & 1 & - & - & 1 & - & 2 & 7 & - & - & - & 4 & - & - & - & - & - & - & 1 & 3 & - & - & 1 & - \\
\hline 18 & Suniotrichus sp. 5 & - & - & - & - & - & - & - & - & 1 & - & - & 2 & - & - & - & - & - & - & - & - & 1 & - & - & - \\
\hline 19 & Thinocharis sp. 1 & - & - & 1 & 6 & - & - & - & 22 & 67 & 14 & 60 & 4 & - & - & - & 10 & - & - & - & 34 & 83 & 10 & 87 & 9 \\
\hline 20 & Thinocharis sp. 2 & - & - & - & - & - & - & - & - & - & - & - & 3 & - & - & 1 & - & - & - & - & - & - & - & - & - \\
\hline 21 & Thinocharis sp. 3 & - & - & 11 & - & 1 & - & - & - & - & - & - & 1 & - & - & 4 & - & - & - & - & - & - & - & - & - \\
\hline 22 & Xenaster sp. 1 & 1 & - & - & - & - & - & 3 & - & 2 & - & - & 2 & - & - & - & - & - & - & - & - & - & - & 1 & 1 \\
\hline 23 & Xenaster sp. 2 & - & - & - & - & - & - & - & - & - & - & - & - & - & - & - & - & - & - & - & 1 & - & - & - & - \\
\hline 24 & Oedichirus sp. 1 & 3 & - & 3 & - & 2 & 1 & 1 & 1 & - & - & 1 & 2 & - & - & - & 1 & - & - & 3 & - & 1 & 2 & - & - \\
\hline 25 & Oedichirus sp. 2 & - & - & - & - & - & - & - & 1 & - & - & 2 & - & - & - & - & - & - & - & - & - & - & - & - & 1 \\
\hline 26 & Oedichirus sp. 4 & - & - & - & 3 & - & - & 1 & 6 & 4 & 1 & 3 & 11 & - & - & - & - & - & - & 1 & 10 & 4 & - & 3 & 5 \\
\hline 27 & Palaminus sp. 4 & - & - & - & - & - & - & - & - & - & - & - & - & 1 & - & - & - & - & - & - & - & - & - & 1 & - \\
\hline \multicolumn{26}{|c|}{ Scaphidiinae } \\
\hline 28 & Baeocera sp. 1 & 1 & - & 1 & 2 & 1 & 1 & 1 & 5 & 4 & 3 & 32 & 3 & - & - & - & - & - & - & - & 1 & 1 & - & 11 & - \\
\hline 29 & Scaphisoma sp. 1 & - & - & - & 1 & - & - & - & 21 & - & 3 & 25 & 9 & - & - & - & - & - & - & - & 17 & 1 & 1 & 20 & - \\
\hline 30 & Scaphisoma sp. 2 & - & - & - & - & - & - & - & - & - & - & - & - & - & - & 1 & - & - & - & - & - & - & - & - & - \\
\hline \multicolumn{26}{|c|}{ Staphylininae } \\
\hline & antholinini & & & & & & & & & & & & & & & & & & & & & & & & \\
\hline 31 & Renda sp. 1 & - & - & - & - & - & - & - & - & - & - & - & - & - & - & - & - & - & - & - & - & 1 & - & - & - \\
\hline 32 & Xantolini MS 1 & - & - & - & - & - & - & - & - & - & - & - & - & - & - & - & - & - & - & - & - & - & - & - & 1 \\
\hline & taphylinini & & & & & & & & & & & & & & & & & & & & & & & & \\
\hline 33 & Philotalpus sp. 1 & 1 & - & - & - & 1 & - & - & 1 & - & - & - & - & - & - & - & - & - & - & - & - & - & - & - & - \\
\hline 34 & Staphylinini MS 1 & - & - & - & - & - & - & - & - & - & 1 & - & - & - & - & - & - & - & - & - & - & - & - & - & - \\
\hline 35 & Xanthypigina MS 1 & - & - & - & - & - & - & - & - & - & 1 & - & - & - & - & - & - & - & - & - & - & 4 & - & - & - \\
\hline & tinae & & & & & & & & & & & & & & & & & & & & & & & & \\
\hline 36 & Piestus schadei & - & - & - & - & - & - & - & - & 8 & 16 & - & 1 & - & - & - & - & - & - & - & 1 & - & - & 4 & - \\
\hline & telinae & & & & & & & & & & & & & & & & & & & & & & & & \\
\hline 37 & Anotylus sp. 1 & - & 1 & - & - & - & - & 1 & 4 & 1 & 16 & - & 10 & - & - & - & - & - & - & - & - & - & - & - & - \\
\hline 38 & Anotylus sp. 4 & - & - & - & - & - & - & - & - & - & - & - & 1 & - & - & - & - & - & - & - & - & - & - & - & - \\
\hline & riinae & & & & & & & & & & & & & & & & & & & & & & & & \\
\hline 39 & Holotrochus micans & - & - & - & - & - & - & - & 3 & - & - & 1 & - & - & - & - & - & - & - & - & - & - & - & - & - \\
\hline 40 & Holotrochus schubarti & - & - & - & - & - & - & - & - & - & - & - & 1 & - & - & - & - & - & - & - & - & - & - & - & - \\
\hline 41 & Holotrochus sp. 1 & - & - & - & - & - & - & - & - & - & - & - & - & - & - & - & - & - & - & - & - & - & - & 1 & - \\
\hline 42 & Holotrochus vianai & - & - & - & - & - & - & - & - & - & - & 1 & - & - & - & - & - & - & - & - & - & - & - & - & - \\
\hline 43 & Osoriellus sp. 2 & - & - & - & - & - & - & - & - & - & - & - & - & - & - & - & - & - & - & - & - & - & - & 1 & - \\
\hline
\end{tabular}


Appendix I. Continued.

\begin{tabular}{|c|c|c|c|c|c|c|c|c|c|c|c|c|c|c|c|c|c|c|c|c|c|c|c|c|c|}
\hline \multirow{3}{*}{ No. } & \multirow{3}{*}{ Species } & \multicolumn{24}{|c|}{ Sampling date and successional stage } \\
\hline & & \multicolumn{12}{|c|}{ July-August 2007} & \multicolumn{12}{|c|}{ April-May 2007} \\
\hline & & $1^{\mathrm{a}}$ & $1^{\mathrm{b}}$ & $1^{\mathrm{c}}$ & $2^{\mathrm{a}}$ & $2^{\mathrm{b}}$ & $2^{\mathrm{c}}$ & $3^{\mathrm{a}}$ & $3^{\mathrm{b}}$ & $3^{c}$ & $4^{\mathrm{a}}$ & $4^{\mathrm{b}}$ & $4^{c}$ & $1^{\mathrm{a}}$ & $1^{\mathrm{b}}$ & $1^{\mathrm{c}}$ & $2^{\mathrm{a}}$ & $2^{\mathrm{b}}$ & $2^{c}$ & $3^{\mathrm{a}}$ & $3^{\mathrm{b}}$ & $3^{\mathrm{c}}$ & $4^{\mathrm{a}}$ & $4^{\mathrm{b}}$ & $4^{\mathrm{c}}$ \\
\hline 44 & Osoriinae MS 1 & - & - & - & - & - & - & - & - & - & - & - & - & - & - & - & - & - & 1 & - & - & - & - & - & - \\
\hline 45 & Osorius peruvianus & - & - & - & - & - & - & - & - & - & - & - & - & - & - & - & - & - & - & - & - & - & - & 2 & - \\
\hline 46 & Osorius piceus & - & - & - & - & - & - & - & - & - & - & - & - & - & - & - & - & - & - & - & - & - & - & 1 & - \\
\hline 47 & Osorius wasmanni & - & - & - & - & - & - & - & - & - & - & 1 & - & - & - & - & - & - & - & - & - & - & - & 13 & - \\
\hline 48 & Ouloglene sp. 1 & - & - & - & - & - & - & - & - & - & 3 & 16 & - & - & - & - & - & - & - & - & - & - & - & - & - \\
\hline \multirow[t]{2}{*}{49} & Thoracophorus sahlbergi & - & - & - & - & - & - & - & - & - & - & - & - & - & - & - & - & - & - & - & - & - & - & - & 1 \\
\hline & \multicolumn{25}{|c|}{ Euaesthetinae } \\
\hline 50 & Edaphus bryanti & - & - & - & - & - & - & - & - & - & 1 & - & - & - & - & - & 1 & - & - & - & - & - & - & - & - \\
\hline 51 & Edaphus depressus & - & - & - & - & - & - & - & - & - & - & 7 & - & - & - & - & 1 & - & - & - & - & - & - & - & - \\
\hline \multirow[t]{2}{*}{52} & Edaphus hoppi & - & - & - & - & - & - & - & - & - & - & 1 & - & - & - & - & - & - & - & - & - & - & - & - & - \\
\hline & inae & & & & & & & & & & & & & & & & & & & & & & & & \\
\hline 53 & Stenus sp. 1 & - & - & - & - & - & - & - & 4 & 3 & - & 1 & 5 & - & - & - & - & - & - & 2 & 1 & 1 & - & - & - \\
\hline 54 & Stenus sp. 2 & - & 1 & - & - & - & - & - & - & - & - & - & - & - & - & - & - & - & - & - & - & - & - & - & - \\
\hline & nyporinae & & & & & & & & & & & & & & & & & & & & & & & & \\
\hline 55 & Bryoporus sp. 1 & - & - & - & - & - & - & - & - & - & - & 1 & - & - & - & - & - & - & - & - & - & - & - & - & - \\
\hline 56 & Cileoporus sp. 1 & - & - & - & - & - & - & - & - & 3 & - & - & - & - & - & - & - & - & - & - & - & - & - & - & - \\
\hline 57 & Coproporus sp. 1 & - & - & - & - & - & - & - & - & - & - & - & - & - & - & - & - & - & - & - & - & - & - & 1 & - \\
\hline 58 & Sepedophilus sp. 1 & - & - & - & 1 & - & - & - & - & - & - & - & 1 & - & - & - & - & - & - & - & - & - & - & - & - \\
\hline 59 & Tachyporinae MS 1 & - & - & - & - & - & - & - & - & - & - & - & - & - & - & - & - & - & - & - & - & - & - & 1 & - \\
\hline 60 & Tachyporinae MS 2 & - & - & - & - & - & - & - & - & - & - & - & - & - & - & - & 1 & - & - & - & - & - & - & - & - \\
\hline 61 & Tachyporinae MS 3 & - & - & - & - & - & - & - & 5 & - & - & - & - & - & - & - & - & - & - & - & - & - & - & - & - \\
\hline & zalopsidiinae & & & & & & & & & & & & & & & & & & & & & & & & \\
\hline 62 & Clivilispinus politus & - & - & - & - & - & - & - & - & - & - & - & - & - & - & - & - & - & - & - & 1 & - & - & - & - \\
\hline & ionidae & & & & & & & & & & & & & & & & & & & & & & & & \\
\hline & ytinae & & & & & & & & & & & & & & & & & & & & & & & & \\
\hline 63 & Molytina MS 1 & - & - & - & 1 & - & - & 1 & - & - & 1 & - & - & - & - & - & - & - & - & 2 & 1 & - & - & 1 & - \\
\hline 64 & Molytina MS 2 & - & - & - & 7 & - & - & 3 & 17 & 7 & 1 & 24 & 12 & - & - & - & 2 & - & - & 6 & 10 & 5 & 2 & 19 & 3 \\
\hline 65 & Conotrachelus sp. 1 & - & - & - & - & - & - & - & 1 & - & - & - & - & - & - & - & - & - & - & - & - & - & - & - & - \\
\hline 66 & Conotrachelus sp. 8 & - & - & - & - & - & - & - & - & - & - & - & - & - & - & - & - & - & - & - & - & - & - & - & 1 \\
\hline 67 & Conotrachelus sp. 5 & - & - & - & 1 & 1 & 1 & - & - & 1 & 1 & - & - & - & - & - & - & - & - & - & - & - & - & - & - \\
\hline 68 & Conotrachelus sp. 7 & - & - & 1 & - & - & - & - & - & - & - & - & - & - & - & - & - & 1 & - & - & - & - & - & - & - \\
\hline 69 & Ithaura anaspis & - & - & - & - & - & - & - & - & - & 4 & 5 & - & - & - & - & - & - & - & - & - & - & - & 1 & - \\
\hline & oderinae & & & & & & & & & & & & & & & & & & & & & & & & \\
\hline 70 & Conoderinae MS 1 & - & - & 2 & 1 & - & - & - & - & 1 & - & 3 & 1 & - & - & - & - & - & 1 & - & - & - & - & - & - \\
\hline & soninae & & & & & & & & & & & & & & & & & & & & & & & & \\
\hline 71 & Cossoninae MS 6 & - & - & - & 1 & - & - & - & - & - & - & - & - & - & - & - & 1 & - & - & - & - & - & - & - & 1 \\
\hline 72 & Cossoninae MS 9 & - & - & - & 1 & - & - & - & - & - & - & - & - & - & - & - & - & - & - & - & - & - & - & 1 & - \\
\hline & ptorhynchinae & & & & & & & & & & & & & & & & & & & & & & & & \\
\hline 73 & Cryptorhynch. Ms 3 & 1 & - & - & - & - & - & - & - & - & - & - & - & - & - & - & - & - & - & - & - & - & - & - & - \\
\hline 74 & Cryptorhynch. Ms 7 & - & - & - & - & - & - & 1 & - & - & 1 & - & - & - & - & - & - & - & - & - & - & - & - & - & - \\
\hline 75 & Cryptorhynch. Ms 8 & - & - & - & - & - & - & - & - & - & - & - & - & 1 & - & - & - & - & - & - & - & - & - & - & - \\
\hline 76 & Cryptorhynch. Ms 9 & 1 & - & 2 & - & - & - & - & - & - & - & - & - & 2 & - & - & - & - & - & - & - & - & - & - & - \\
\hline 77 & Tylodes sp. 1 & - & - & - & - & - & - & - & 1 & - & - & - & - & - & - & - & - & - & - & - & - & - & - & - & - \\
\hline 78 & Tylodina MS 18 & - & - & - & 1 & - & - & - & - & - & - & - & - & - & - & - & - & - & - & - & - & - & - & - & - \\
\hline 79 & Tylodina MS 8 & - & - & - & - & - & - & - & 4 & - & 1 & 4 & 2 & - & - & - & - & - & - & - & 4 & - & - & - & - \\
\hline 80 & Tylodina MS 11 & - & - & - & 3 & - & - & 8 & - & - & 1 & 2 & 7 & - & - & - & 1 & - & - & 6 & - & - & - & - & 5 \\
\hline 81 & Tylodina MS 16 & - & - & - & 11 & - & 2 & - & - & 7 & - & - & - & - & - & - & - & - & 1 & - & - & 9 & - & - & - \\
\hline 82 & Tylodina MS 1 & - & - & - & 1 & - & - & 3 & 6 & 14 & 6 & 14 & 9 & - & - & - & 1 & - & - & 1 & - & 1 & - & 4 & - \\
\hline 83 & Tylodina MS 3 & - & - & - & - & - & - & - & 6 & - & 2 & - & - & - & - & - & - & - & - & - & 3 & 1 & - & - & - \\
\hline 84 & Tylodina MS 6 & - & - & - & - & - & - & - & 2 & 1 & 1 & 3 & - & - & - & - & - & - & - & - & 4 & 1 & - & 1 & - \\
\hline 85 & Tylodina MS 7 & - & - & - & 1 & 1 & 1 & 4 & 21 & 4 & 9 & 40 & 44 & - & - & - & - & - & - & 1 & 6 & - & 2 & 25 & 1 \\
\hline 86 & Tylodina MS 15 & - & - & - & 5 & - & - & - & 2 & 2 & 1 & - & 1 & - & - & - & - & - & - & - & 1 & 2 & - & - & - \\
\hline & hininae & & & & & & & & & & & & & & & & & & & & & & & & \\
\hline 87 & Oryzophagus oryzae & - & - & - & - & - & - & - & - & - & - & - & - & - & - & - & - & 1 & - & 1 & - & - & - & - & - \\
\hline
\end{tabular}


Appendix I. Continued.

Sampling date and successional stage

\begin{tabular}{|c|c|c|c|c|c|c|c|c|c|c|c|c|c|c|c|c|c|c|c|c|c|c|c|c|c|}
\hline \multirow{3}{*}{ No. } & \multirow{3}{*}{ Species } & \multicolumn{24}{|c|}{ Sampling date and successional stage } \\
\hline & & \multicolumn{12}{|c|}{ July-August 2007} & \multicolumn{12}{|c|}{ April-May 2007} \\
\hline & & $1^{\text {a }}$ & $1^{\mathrm{b}}$ & $1^{\mathrm{c}}$ & $2^{\mathrm{a}}$ & $2^{\mathrm{b}}$ & $2^{\mathrm{c}}$ & $3^{\mathrm{a}}$ & $3^{\mathrm{b}}$ & $3^{c}$ & $4^{\mathrm{a}}$ & $4^{b}$ & $4^{c}$ & $1^{\mathrm{a}}$ & $1^{\mathrm{b}}$ & $1^{\mathrm{c}}$ & $2^{\mathrm{a}}$ & $2^{\mathrm{b}}$ & $2^{c}$ & $3^{\mathrm{a}}$ & $3^{b}$ & $3^{c}$ & $4^{\mathrm{a}}$ & $4^{b}$ & $4^{c}$ \\
\hline \multicolumn{26}{|c|}{ Baridinae } \\
\hline 88 & Baridinae MS 2 & - & - & - & - & - & - & - & 1 & - & - & - & - & - & - & - & - & - & - & - & - & - & - & - & - \\
\hline 89 & Baridinae MS 4 & - & - & - & - & - & - & - & 1 & - & - & - & - & - & - & - & - & - & - & - & - & - & - & - & - \\
\hline \multicolumn{26}{|c|}{ Entiminae } \\
\hline 90 & Naupactus sp. 1 & - & - & 1 & - & - & - & - & - & - & - & - & - & - & - & - & - & - & - & - & - & - & - & - & - \\
\hline \multicolumn{26}{|c|}{ Anypotactini } \\
\hline 91 & Hypantus teretirostris & - & 2 & - & - & - & - & - & - & - & - & - & - & - & - & - & - & - & - & - & - & - & - & - & - \\
\hline \multicolumn{26}{|c|}{ Rhythirrininae } \\
\hline 92 & Listronotus sp. 1 & - & 1 & - & - & - & - & - & - & - & - & - & - & - & - & - & - & - & - & - & - & - & - & - & - \\
\hline \multicolumn{26}{|c|}{ Apioninae } \\
\hline 93 & Apion sp. 2 & - & 1 & - & - & - & - & - & - & - & - & - & - & - & - & - & - & - & - & - & - & - & - & - & - \\
\hline \multicolumn{26}{|c|}{ Curculioninae } \\
\hline 94 & Anthonomus sp. 1 & 1 & - & - & - & - & - & - & - & - & - & - & - & - & - & - & - & - & - & - & - & - & - & - & - \\
\hline 95 & Sibinia sp. 1 & - & - & - & - & - & - & - & - & - & - & - & - & 1 & - & - & - & - & - & - & - & - & - & - & - \\
\hline \multicolumn{26}{|c|}{ Eugnominae } \\
\hline 96 & Udeus sp. 2 & - & - & - & - & - & - & - & 1 & - & - & - & - & - & - & - & - & - & - & - & - & - & - & - & - \\
\hline \multicolumn{26}{|c|}{ Carabidae } \\
\hline \multicolumn{26}{|c|}{ Carabinae } \\
\hline 97 & Pseudaptinus sp. 1 & 1 & - & 1 & - & - & - & - & - & - & - & - & - & - & - & - & - & - & - & - & - & - & - & - & - \\
\hline 98 & Pseudaptinus sp. 2 & - & - & - & - & - & - & - & - & - & - & 2 & - & - & - & - & - & - & - & - & - & - & - & - & - \\
\hline 99 & Paratachys sp. 1 & - & - & - & 1 & - & - & - & 26 & - & 1 & 1 & 24 & - & - & - & 4 & - & - & - & 7 & 1 & 3 & 2 & 1 \\
\hline 100 & Paratachys sp. 2 & - & - & - & - & - & - & - & 1 & - & 1 & - & - & - & - & - & - & - & - & - & - & - & 2 & - & - \\
\hline 101 & Paratachys sp. 3 & - & - & - & - & - & - & - & - & - & - & - & 1 & - & - & - & - & - & - & - & - & - & - & - & - \\
\hline 102 & Paratachys sp. 9 & - & - & - & - & - & - & - & - & - & - & - & - & - & - & - & - & - & - & - & - & - & - & 2 & - \\
\hline 103 & Paratachys sp. 10 & - & 11 & 1 & - & - & - & - & - & - & - & - & - & - & - & - & - & - & - & - & - & - & - & - & - \\
\hline 104 & Paratachys sp. 11 & - & - & 1 & - & - & - & - & - & - & - & - & - & - & - & - & - & - & - & - & - & - & - & - & - \\
\hline 105 & Polyderidius sp. 1 & - & 4 & 3 & - & - & - & - & - & - & - & - & - & - & - & - & - & - & - & - & - & - & - & - & - \\
\hline 106 & Xystosomus inflatus & 1 & - & - & 1 & - & - & - & 15 & 11 & 6 & 18 & 16 & - & - & - & - & - & - & - & 4 & 2 & 1 & 4 & 6 \\
\hline 107 & Xystosomus tholus & - & - & - & 45 & - & 6 & 59 & 114 & 77 & 19 & 99 & 41 & - & - & - & 25 & - & 2 & 8 & 37 & 20 & 7 & 62 & 14 \\
\hline 108 & Pentagonica media & - & - & - & - & - & - & - & 1 & - & - & - & - & - & - & - & - & - & - & - & - & - & - & - & - \\
\hline 109 & Pentagonica sp. 2 & - & - & - & - & - & - & - & - & - & - & - & 2 & - & - & - & - & - & - & - & - & - & - & - & - \\
\hline 110 & Pentagonica sp. 4 & - & - & - & - & - & - & - & - & - & - & - & - & - & - & - & - & - & - & - & 1 & - & - & - & 1 \\
\hline
\end{tabular}

Harpalinae

Lebia sp. 1

Apenes sp. 1

Harpalini MS 1

Selenophorus sp. 2

Selenophorus sp. 3

Selenophorus sp. 4

Selenophorus sp. 6

Selenophorus sp. 7

Loxandrus sp. 2

Loxandrus sp. 3

$121 \quad$ Helluomorpha sp.

Endomychidae

Eupsilobiinae

Cerylonidae
123 Cerylonidae Ms 2
$124 \quad$ Philothermus sp. 1
125 Lapethus sp. 2
Leiodidae
$126 \quad$ Leiodidae MS 2
127 Leiodidae MS 5


Appendix I. Continued.

\begin{tabular}{|c|c|c|c|c|c|c|c|c|c|c|c|c|c|c|c|c|c|c|c|c|c|c|c|c|c|}
\hline \multirow{3}{*}{ No. } & \multirow{3}{*}{ Species } & \multicolumn{24}{|c|}{ Sampling date and successional stage } \\
\hline & & \multicolumn{12}{|c|}{ July-August 2007} & \multicolumn{12}{|c|}{ April-May 2007} \\
\hline & & $1^{\mathrm{a}}$ & $1^{\mathrm{b}}$ & $1^{\mathrm{c}}$ & $2^{\mathrm{a}}$ & $2^{\mathrm{b}}$ & $2^{\mathrm{c}}$ & $3^{\mathrm{a}}$ & $3^{\mathrm{b}}$ & $3^{\mathrm{c}}$ & $4^{\mathrm{a}}$ & $4^{\mathrm{b}}$ & $4^{c}$ & $1^{\mathrm{a}}$ & $1^{\mathrm{b}}$ & $1^{\mathrm{c}}$ & $2^{\mathrm{a}}$ & $2^{\mathrm{b}}$ & $2^{c}$ & $3^{\mathrm{a}}$ & $3^{\mathrm{b}}$ & $3^{\mathrm{c}}$ & $4^{\mathrm{a}}$ & $4^{\mathrm{b}}$ & $4^{c}$ \\
\hline 128 & Aglyptinus sp. 2 & - & - & - & - & - & - & - & 1 & - & - & - & - & - & - & - & - & - & - & - & - & - & - & - & - \\
\hline 129 & Eucatops sp. 1 & - & - & - & 11 & - & 13 & 5 & 24 & 16 & 6 & 10 & 8 & - & - & - & 5 & - & - & 1 & 1 & 3 & 2 & 4 & 1 \\
\hline 130 & Paulipalpina sp. 1 & - & - & - & - & - & - & - & 24 & - & 1 & - & - & - & - & - & - & - & - & - & 9 & - & 2 & 1 & - \\
\hline \multicolumn{26}{|c|}{ Tenebrionidae } \\
\hline 131 & Tenebrionidae MS 1 & - & - & - & 2 & - & - & - & - & - & - & - & - & - & - & - & - & - & - & - & - & - & - & - & - \\
\hline 132 & Tenebrionidae MS 2 & - & - & - & - & - & - & - & - & - & - & - & - & - & - & - & - & - & - & - & 1 & - & - & - & - \\
\hline 133 & Tenebrionidae MS 3 & - & 1 & - & - & - & - & - & - & - & - & - & - & - & - & - & - & - & - & - & - & - & - & - & - \\
\hline 134 & Tenebrionidae MS 4 & - & - & - & - & - & - & - & - & - & - & 1 & - & - & - & - & - & - & - & - & - & - & - & - & - \\
\hline 135 & Tenebrionidae MS 5 & - & - & - & - & - & - & - & - & - & - & - & - & - & - & - & - & - & - & - & 1 & - & - & - & - \\
\hline 136 & Tenebrionidae MS 7 & - & - & - & - & - & - & - & - & - & - & - & - & - & - & - & 1 & - & - & - & - & - & - & - & - \\
\hline 137 & Tenebrionidae MS 8 & - & - & - & - & - & - & - & - & - & - & - & - & - & - & - & - & - & - & 1 & - & - & - & - & - \\
\hline 138 & Tenebrionidae MS 9 & - & - & - & - & - & - & - & 1 & - & 1 & - & 1 & - & - & - & - & - & - & - & - & - & - & - & - \\
\hline 139 & Tenebrionidae MS 10 & - & - & - & - & - & - & - & 1 & - & - & - & - & - & - & - & - & - & - & - & - & - & - & - & - \\
\hline 140 & Tenebrionidae MS 11 & - & - & 1 & - & - & - & - & - & - & - & - & - & - & - & - & - & - & - & - & - & - & - & - & - \\
\hline 141 & Tenebrionidae MS 13 & - & - & - & - & - & - & - & - & - & - & - & - & - & - & - & - & - & - & 1 & - & - & - & - & - \\
\hline 142 & Anaedus sp. 1 & - & - & - & - & - & - & - & - & - & - & - & 2 & - & - & - & - & - & - & - & - & - & - & - & - \\
\hline 143 & Anaedus sp. 3 & - & 3 & 1 & 1 & 4 & 1 & 3 & 1 & 1 & 1 & 1 & - & - & - & 1 & 1 & - & - & - & - & - & - & - & 1 \\
\hline 144 & Anaedus sp. 4 & - & - & - & - & - & 4 & 1 & 4 & - & 1 & 8 & 1 & - & - & - & 1 & - & 1 & - & - & 2 & 1 & 2 & 1 \\
\hline 145 & Anaedus sp. 7 & - & - & - & - & - & - & - & - & - & - & - & 1 & - & - & - & - & - & - & 1 & - & - & - & - & 1 \\
\hline 146 & Anaedus sp. 9 & - & 1 & - & - & - & - & - & - & - & - & - & - & - & - & - & - & - & - & - & - & - & - & - & - \\
\hline 147 & Anaedus sp. 10 & - & 1 & - & - & - & - & - & - & - & - & - & - & - & - & - & - & - & - & - & - & - & - & - & - \\
\hline 148 & Anaedus sp. 12 & - & - & - & - & - & - & - & - & - & - & - & 1 & - & - & - & - & - & - & - & - & - & - & - & - \\
\hline 149 & Platydema sp. 1 & - & - & - & 1 & - & - & - & - & - & - & - & 7 & - & - & - & - & - & - & - & - & - & 1 & - & 2 \\
\hline 150 & Tyrtaeus plaumanni & - & - & - & - & - & - & - & - & 1 & - & - & - & - & - & - & - & - & - & - & - & - & - & - & - \\
\hline \multicolumn{26}{|c|}{ Phrenapatinae } \\
\hline 151 & Peneta sp. 2 & - & - & - & - & - & - & - & - & - & - & - & 1 & - & - & - & - & - & - & - & - & - & - & - & - \\
\hline \multicolumn{26}{|c|}{ Hydrophilidae } \\
\hline 152 & Hydrophilidae MS 2 & - & - & - & - & - & 1 & - & - & - & - & - & 2 & - & - & - & - & - & - & - & 1 & - & 1 & - & - \\
\hline 153 & Cyclotypus sp. 1 & - & - & - & - & 1 & - & - & - & - & 1 & - & - & - & - & - & - & - & - & - & - & 3 & 2 & - & - \\
\hline 154 & Phaenonotum sp. 1 & - & - & - & - & - & - & - & - & - & - & - & - & 3 & 1 & 1 & - & - & - & - & - & - & - & - & - \\
\hline \multicolumn{26}{|c|}{ Eucinetidae } \\
\hline 155 & Jentozkus sp. 1 & - & - & - & - & - & - & - & - & 1 & - & - & 1 & - & - & - & - & - & - & - & - & - & - & - & - \\
\hline
\end{tabular}

